Florida International University FIU Digital Commons

$11-13-2013$

\title{
Traces of the Dark Sublime in William Faulkner's "The Bear," Light in August, and Absalom, Absalom!
}

Manuel Delgadillo

mdelg078@fiu.edu

DOI: $10.25148 /$ etd.FI13120423

Follow this and additional works at: https://digitalcommons.fiu.edu/etd

Part of the English Language and Literature Commons

\section{Recommended Citation}

Delgadillo, Manuel, "Traces of the Dark Sublime in William Faulkner's "The Bear," Light in August, and Absalom, Absalom!" (2013). FIU Electronic Theses and Dissertations. 990.

https://digitalcommons.fiu.edu/etd/990 


\section{FLORIDA INTERNATIONAL UNIVERSITY}

Miami, Florida

TRACES OF THE DARK SUBLIME IN WILLIAM FAULKNER'S “THE BEAR,” LIGHT IN AUGUST, AND ABSALOM, ABSALOM!

A thesis submitted in partial fulfillment of the

requirements for the degree of

MASTER OF ARTS

in

ENGLISH

by

Manuel Delgadillo

2013 
To: Dean Kenneth G. Furton

College of Arts and Sciences

This thesis, written by Manuel Delgadillo, and entitled Traces of the Dark Sublime in William Faulkner's "The Bear," Light in August, and Absalom, Absalom!, having been approved in respect to style and intellectual content, is referred to you for judgment.

We have read this thesis and recommend that it be approved.

$\begin{array}{r}\hline \text { Nathaniel Cadle } \\ \hline \text { Michael P. Gillespie } \\ \hline \text { Bruce Harvey, Major Professor }\end{array}$

Date of Defense: November 13, 2013

The thesis of Manuel Delgadillo is approved.

Dean Kenneth G. Furton
College of Arts and Sciences

Dean Lakshmi N. Reddi University Graduate School

Florida International University, 2013 


\section{DEDICATION}

I dedicate this thesis to a number of people: my mother and father, both of whom showed me the value of humility and the necessity of utter dedication to any task at hand; to Hermes Diaz, who fostered in me the love of art and literature from an early age; and to Daliz L. Rivas, whose immense and incommensurable companionship and love I hold dear. 


\section{ACKNOWLEDGMENTS}

I want to thank the members of my committee for their support, motivation, and for challenging me to think in alternative and sometimes unpredictable ways. I wish to thank Dr. Harvey for helping me develop my intellectual and academic interests, and for allowing me the interpretive flexibility necessary to undertake an indeed sublime task. I want to thank Dr. Cadle for his helpful resources, and for deepening my understanding of modernist literature and its theoretical legacies. I also thank Dr. Gillespie for his genuine affection and support, and for allowing me the freedom to explore literature and literary analysis in more than one way.

I would also like to acknowledge Dr. Milbauer, without whose stimulation and constant advice, academic and otherwise, I could not have made it this far, and Alexandra Palacios, whose relentless enthusiasm helped me foster my own. 


\author{
ABSTRACT OF THE THESIS \\ TRACES OF THE DARK SUBLIME \\ IN WILLIAM FAULKNER’S “THE BEAR,” LIGHT IN AUGUST, \\ AND ABSALOM, ABSALOM! \\ by \\ Manuel Delgadillo \\ Florida International University, 2013 \\ Miami, Florida \\ Professor Bruce Harvey, Major Professor
}

The purpose of this thesis is to explore William Faulkner's paradoxical modernist aesthetic. While his writings evince primal, earthy, and post-Civil War angst-ridden qualities, Faulkner's narratives are also found to be hyper-postmodern. Using Jacques Derrida's theories on the absent-present trace, I will show how certain micromoments in three of Faulkner's texts showcase the "trace" forming a pathway to the inaccessible and unattainable sublime. I will use "trace" and general theories of the "sublime" as methodological tools to explore Faulkner's narrative of pastoral loss, the cultural institutionalization of racial differences, as well as structures of mourning/melancholia that lead to the disruption of the pathway between trace and sublime. The imagery/narrative palpability, manifested through Faulkner's pictorial imagination, brings Derridean theory to earth, yet meanwhile transcends any theoretical or conceptual methodology. The three micromoments will reveal ruptures (irreconcilable meanings) at work in the margins of these texts. 


\section{TABLE OF CONTENTS}

CHAPTER

PAGE

INTRODUCTION

There is Nothing Outside the Trace: William Faulkner and the Sublime. 1

CHAPTER ONE

The Pathway to the Pastoral Sublime: The Deictic Trace in "The Bear"................17

CHAPTER TWO

(T)race and Crypto-Genealogies in Light in August................................42

CHAPTER THREE

'The Maelstrom of Unbearable Reality': The Trace as

Ghost-Image in Absalom, Absalom!

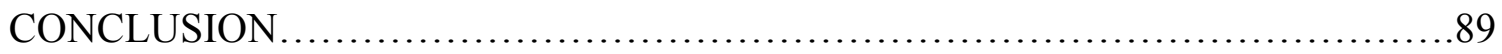

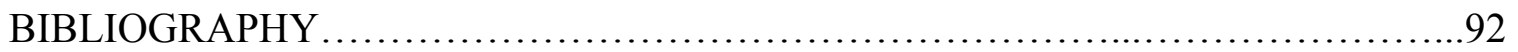




\section{INTRODUCTION}

There is Nothing Outside the Trace: William Faulkner and the Sublime

The problematic of William Faulkner's (1897-1962) modernist aesthetic can be summarily conveyed through a simple formula: Faulkner is a modernist writer who is also obliged, paradoxically, to deal with the legacy of Southern history. Faulkner's insistence on representing the history of the South within a modernist framework was expounded upon in a 1938 book review of his novel, The Unvanquished, by the Argentine writer Jorge Luis Borges. Writing for El Hogar (Home) Magazine, Borges applauded Faulkner's literary realism and his ability to represent a pure verisimilitude: "Faulkner...at times wants to recreate the pure present, neither simplified by time nor polished by attention. The 'pure present' is no more than a psychological ideal—and thus some of Faulkner's decompositions are more confused—and richer—-than the original events" (Selected Non-Fictions 186). Significantly, Borges seems to hint at the possibility of a discourse in which the text reveals the "blood relation of ...America...and its history" (186); in other words, a discourse which reveals the text functioning as a genealogical trace of America and its history. Indeed, Faulkner is an author whose preoccupation with the meaningful part of history, racial identity and race relations, the displacement of chronology, pastoral loss, family decline and the decay of the homeland, gendered hierarchies, humanity's endurance in the face of change, and post-Civil War loss of honor are patterns that form a network of themes present throughout his novels and short stories, political essays and letters. A particular way of exploring Faulkner's modernist aesthetic is by relocating the major motifs that constitute his work within the theoretical domain of the sublime and the absent-present trace. The sublime and the 
poststructuralist notion of trace are particular methodological tools intended to interrogate and aid in the understanding of the complexity of Faulkner's modernist fiction. ${ }^{1}$

Many of the aforementioned themes and literary preoccupations may be traced to Faulkner's own biography. Faulkner's near-obsessive reverence of his great-grandfather, the Civil War colonel William Clark Falkner (the ' $u$ ' was added by Faulkner himself after enlisting in the Royal Air Force), coupled with tales of old war veterans, presumably sparked Faulkner's interest in Southern history, the memorialization of the past, and indeed what Irving Howe in his critical study of Faulkner calls "the Southern memory, the Southern myth, the Southern reality" (A Critical Study 21). In his sociological study of Faulkner's fiction, Irving Howe discusses the writer's major themes within the context of Southern myth and tradition; for Howe, "human rootlessness in the modern world" (6) comprises Faulkner's view of the modern individual—as well as the individual person caught in the tension between urbanism/expansionism and the Southern agrarian tradition - while Yoknapatawpha County becomes the "setting for a complex moral chronicle in which a popular myth and an almost legendary past yield something quite rare in American literature: a deep sense of the burdens and grandeur of history" (Irving $3)$.

In terms of the pervasive themes that constitute Faulkner's oeuvre, the literary influences of his friend Phil Stone and Sherwood Anderson (whom Faulkner met in New Orleans) and other aspects of Faulkner's life and artistic ideals, shaped the motifs, critiques, and modernist stylistics that run like a thread throughout his body of literary

\footnotetext{
${ }^{1}$ In a footnote to the essay "Faulkner and Postmodernism" Patrick O'Donnell emphasizes Richard Moreland's view that Faulkner both inscribes and resists "modernist fascinations with hierarchy, genealogy, and the categorizing of the 'Other'" (O'Donnell 49). The trace and its Other, the sublime, are therefore useful tools in the interrogation of these "fascinations."
} 
work. Yet perhaps the most intriguing dimension of Faulkner's thematic is the failure of the artist to fully capture social and cultural realities in a befitting artistic medium. As Susan Donaldson has pointed out, in his early career, "art for him evoked a struggle for vision so ambitious in its reach that it was ultimately defined by its unattainability and failure, its sublimity, as it were" (“Faulkner’s Versions” 359). Faulkner's own insistence that his 1929 modernist work The Sound and the Fury was a "most splendid failure" (qtd. in Donaldson 359) perhaps signals his emphasis on, and awareness of, the sublime as a space that cannot be broached or attained. Since the sublime marks the failure of the imagination to present an adequate representation of the object of sublimity (within an artistic medium), Faulkner's "failure" is indicative of his own attempt at grasping the heights of literary sublimity.

In her article "Faulkner's Versions of Pastoral, Gothic, and the Sublime" Susan Donaldson points out that the quest for amplitude (the sublime) and its inevitable failure has comprised the thematic for much of his early work, such as the story "Nympholepsy," in which the unattainable nymph is always beyond the grasp of the farmhand, leaving the latter "mourning her absence in bewildered pain" (365). "Nympholepsy" is evocative of the sublime; his later novels would also invoke the sublime in a similar manner, but within the context of race/otherness, pastoralism, historical representation, and mourning. The trace and its counterpart, the sublime, will therefore help in the examination of the structures of meaning underlying these themes as found in Faulkner's texts. The present introduction will focus on defining these key terms, tracing their history, and showing their applicability to Faulkner's “The Bear," Light in August, and Absalom, Absalom! 
The "sublime" as a literary term, aesthetic category, and experiential condition has been widely debated by critics, theorists, and historians over the past few centuries. The history of the sublime is complex and its application varies from century to century. In fact, the last few centuries have witnessed a proliferation of diverse types of sublimes, ranging from the technological sublime, the atomic sublime, the gothic, pastoral, racial, feminine, ecological, and others. The gamut of meanings and applications undeniably attest to the sublime's critical and philosophical contemporary importance.

The sublime refers to sensations of overwhelming awe, grandeur, obscurity, vastness, and infinity before a vast or magnificent object, work of art, idea, or event; in terms of representation, the sublime (which in fact remains indescribable) relays the unrepresentable and unattainable - language and the imagination cannot, because of their limitations, capture and duplicate the object of sublimity. In terms of defining or presenting the object of sublimity (whether an event, an object, idea, or the thoughts in one's head) points of comparison vanish. Therefore, inherent in the concept of sublimity is the profound gulf between what an individual can conceive and what the world renders as possible of conceiving or representing. The material tools afforded to the arts are limited and hence artistic representation cannot fully "present" (in language or painting, for example) the sublime object or experience-it is always unattainable and inexpressible in its overwhelming intensity. The universe, for example, is indescribable; the sublime marks the failure, both cognitive and descriptive, to fully provide an adequate description of the universe through the use of language and through some form of artistic representation. On the other hand, the object of sublimity does not necessarily entail vast, malignant objects; even infinitesimal material objects (an atom, for example) can inspire 
feats of sublimity (the infinity of descriptions that try to capture the minutia of said object is an example of trying to represent and capture this miniscule sublime object). Therefore, the sublime is also linked to commonplace and everyday objects of experiential phenomena.

A historical overview of the sublime, which in reality cannot be fully defined and explained, will be helpful in understanding the different nuances that constitute this term. The history of the term sublime - deriving from the Latin sublimis ${ }^{2}$ - begins with the Greek rhetorician Longinus (first-century C.E.), who in his treatise Peri hupsous (On Sublimity) links the sublime with the affective, emotive functions of profound thoughts and noble passions and the rhetorical functions of noble diction, dignified word arrangement, and certain figures of thought and speech (Longinus 138). Longinus locates the sublime within the domain of rhetoric; more specifically, the sublime renders ekstasis possible once noble and profound thoughts correspond to lofty and expressive language, and therefore sublimity is connected to the thoughts and passions of the creative genius. The genius must deploy effective oratorical devices in order to ravish audiences, thus achieving rhetorical sublimity. For Longinus, these noble qualities embodied the intellect of the genius (like Plato, whom Longinus regards as a sublime writer): "The sublime is the echo of a noble mind" (Longinus 139).

Sublimity in writing and oratory characterizes Longinian philosophy; elevated speech or writing is indicative of noble, lofty ideas in the orator/writer. ${ }^{3}$ Features of

\footnotetext{
${ }^{2}$ From sub (up to) and limen (lintel: the top, horizontal beam of a door). The Greek rendition is hupsous, meaning high-up or upwards.

${ }^{3}$ For Longinus, emotional psychology and efficacious rhetorical devices (like hyperbole, for example) constitute the sublime.
} 
excellency in writing and oratory were thus markers of true and noble sublimity: the Longinian sublime "describe[s] a mode of written or spoken discourse" and the "aesthetic sublime or sublimity...isolates a particular kind of ecstatic experience or state involving feelings of elevation, transcendence, awe, fear, and shock, excited by being in the presence of something greater than oneself' (Costelloe 52). Peri hupsous, apparently lost and therefore unread during the Middle Ages, was translated into Latin and Italian during the Renaissance (in the sixteenth-century), and later in French by Nicholas Boileau in 1674. As a matter of fact, Boileaus's translation revolutionized the field of aesthetics and commenced the trajectory of one of the most ambiguous and contestable terms in critical history.

Following Boileaus's translation-which helped spread Longinus's treatise across Europe - many other writers and critics in the eighteenth-century (pre-Burkean and Kantian) attempted to refine the category of the sublime. ${ }^{4}$ Critics, writers, and philosophers such as Thomas Burnett, the Earl of Shaftsbury, Joseph Addison, John Dennis, and John Baillie consolidated the status of the concept of the sublime as an object of critical and philosophical inquiry. For Neo-Platonist and Christian thinkers like Shaftsbury, the sublime, manifested in the irregular and majestic objects found in nature, were the palpable manifestations of the majesty of the divine God. Joseph Addison, the essayist for the popular periodical The Spectator, edited in 1712, refined the concept of sublimity by speaking of vastness, the awe-inspiring phenomena of natural scenes and landscapes, indeed: "A pleasing kind of horror in the mind" (qtd. in Donaldson 364).

\footnotetext{
${ }^{4}$ With William Smith's 1739 edition of On Sublimity, the sublime "reached a wider public" (Shaw 27).
} 
Already one perceives the perplexing ambiguities that would come to characterize the sublime as a critical and aesthetic term. Indeed, the eighteenth-century witnessed a shift in the concept of the sublime; no longer dependent on sheer rhetoricity, the sublime came to be viewed as a mode of consciousness. The Longinian tradition of sublimity thus dwindled in the eighteenth-century.

For the Irish politician and philosopher Edmund Burke, the sublime is "the strongest emotion which the mind is capable of feeling" (Burke 459). Burke's analysis is more profoundly rigorous and analytical than Addison's and other contemporary British critics and theorists. In shorthand, Burke relocates Lockian empiricism to the domain of aesthetics. In his A Philosophical Enquiry into the Origin of Our Ideas of the Sublime and Beautiful (1757) there takes place a conceptual shift; sublimity is no longer so much a quality found in the external world (nature) but rather an effect of the processes of our mental state. As Philip Shaw suggests, there exists in Burke's text the possibility of the sublime as an "effect of language" (Shaw 49). Burke also differs from his antecedents through his exploration of the psychology of terror characterizing the sublime experience. Moreover, Burke makes a clear distinction between the sublime and the beautiful. The sublime entails obscurity, overwhelming awe, infinity, terror, and fear before frightening, dimensionless phenomena in nature or in inspiring works of literature and art; the beautiful on the other hand is associated with bright coloration, smallness, harmless, finite objects or phenomena found in nature or art. ${ }^{5}$

\footnotetext{
${ }^{5}$ Indeed, the masculine sublime is constructed by Burke as an authoritarian father, while the feminized beautiful is analogized to a "mother's fondness and indulgence" (qtd. in Shaw 57).
} 
Burke's contribution to the discourse on the sublime - and which is applicable to the trace — is the idea that the proper aesthetic distance is prerequisite for the appreciation and interpretation of the moment of sublimity: "the threat of violence is mitigated by the effects of distance" (Shaw 6). As I will later explain, the "pathway" between trace and sublime implies distantiation. In Burke's inquiry we sense the ambiguities and tensions of the concept of sublimity: whether referring to a reader's or viewer's affective response to either a work of literature or art, or whether the sublime itself is a property in art or nature, or whether it is veritably representative of the creative genius of the artist, or in fact whether it is purely subjective, all connotes and denotes the characteristics of the sublime as either an experience of a heightened sensation mingling delight and fear, or as a property operative in art/literature.

Burke expounds upon the dichotomies fear/delight and pain/pleasure that come about when encountering the object of sublimity. The irrational aspects of the sublime (terror, fear, obscurity) are essential to the sublime experience, as long as it is experienced at a distance. ${ }^{6}$ The admixtures of pain and pleasure, fear and delight, or joy and grief distinguish the sublime experience. Although John Baillie had previously described the qualities of fear and delight as paradigmatic of sublime experience, Burke's emphasis on the affective psychology of terror and cognitive distantiation distinguishes him from his predecessors. According to Rodolphe Gasché, terror is the "ruling principle” in Burke's conception of the sublime (“...And the Beautiful?” 28).

With Edmund Burke and later Immanuel Kant, we witness a shift from the sublime in terms of nature and natural phenomena to the sublime as an aspect in

\footnotetext{
${ }^{6}$ According to Burke, the source of the sublime arises in "whatever is in any sort terrible, or is conversant about terrible objects, or operates in a manner analogous to terror" (Burke 459).
} 
language, which, according to Philip Shaw, no longer renders it dependent upon the natural world (Shaw 47). For Kant, the sublime allows one to experience the limits of the sensible world. Moreover, Kant makes a distinction between what he calls the mathematical and dynamical sublimes. The mathematical sublime entails the trumping of the imagination by the vastness and formlessness of the object of sublimity; therefore, this sublime experience cannot be adequately represented. The dynamical sublime is characterized by anything that overpowers an individual's abilities and capacities. ${ }^{7}$ In addition, Kant also distinguishes between the beautiful, characterized by boundedness and form, and the sublime, characterized by formlessness and unboundedness. Kant also stresses the dichotomy attraction/repulsion as typical of the sublime experience: "the feeling of the sublime is a feeling of displeasure that arises from the imagination's inadequacy, in an aesthetic estimation of magnitude... but it is at the same time also a pleasure" (qtd. in Shaw 83). Kant also agrees with Burke that the sublime is not a quality found in natural objects, but rather exists in our cognitive, mental processes.

Kant's philosophical inquiry into the sublime had a profound impact on German Idealist philosophers, including Schiller and Hegel, as well as British Romantics, in particular William Wordsworth and Samuel Taylor Coleridge. Wordsworth sought Enlightenment in the sublime experience; on the other hand, he underscored the impossibility of attainting the sublime ideal. Conversely, Coleridge tried to reconcile the gap between presentation and the unpresentable. Finally, I will finish the present historical overview with the postmodernist conception of the sublime, and show how the

\footnotetext{
${ }^{7}$ In other words, the mathematical sublime is characterized by spatial extension, while the dynamical is characterized by extension in terms of power.
} 
sublime relates to the concept of "trace" and its theoretical applicability to Faulkner's fiction.

The postmodernist rendition of the sublime foregrounds - indeed consolidatesthe elements of unattainability and unrepresentability characterizing the ideas and theories of previous philosophers of the sublime. For postmodernists like Jacques Derrida and Jean-Francois Lyotard, the sublime entails a plurality in language that renders meaning incapable of achieving a fixed, stable form. Language cannot express the absolute, and meaning itself is fragmented and broken: "There is no possibility for absolute unmediated meaning...meaning is always broken, made up of fragments that can never add up to an accessible totality" (Murfin 290). The postmodern sublime celebrates the "ability" to capture our "inability" to fully comprehend the absolute; in other words, the postmodern sublime, while rejecting Romantic notions of transcendence, reason, and nature, refuses to link the vast, fearful, and the unbounded with notions of the divine or reason. Rather, the postmodern sublime upholds the inability to account for the vast and dimensionless. Lyotard, for example, champions the notion that the postmodern sublime "puts forward the unpresentable in presentation itself" (qtd. in Johnson 122) and therefore seeks recourse in abstract forms of art. The postmodern sublime differs from Romantic notions of the sublime in its insistence on immanence rather than transcendence. More importantly, and significant to my study of Faulkner's fiction, is the postmodernist emphasis on the relationship between the sublime and difference/otherness.

Susan Donaldson schematizes the sublime as a) elusive (both the trace and the sublime are elusive phenomena), and emphasizes b) its strangeness and otherness. I will repeatedly refer to as well as problematize her schema, especially in my analysis of race 
and racial difference in Light in August. In the postmodernist conception of the sublime, the imagination encounters its limit when it tries to present an object that is otherwise unpresentable (Johnson 118). The postmodern sublime foregrounds the issue of irresolvability in terms of what can/cannot be presented. In fact, Lyotard's reinterpretation of the Kantian sublime stresses the nature of the conflict of irresolvability between presentation and the object it strives inexorably to present.

What material things, therefore, constitute traces? How does the sublime relate to the concept of the absent-present trace? More importantly, how does the trace/sublime as methodological tools help explicate Faulkner's major modernist motifs? In the preface to Jacques Derrida's Of Grammatology, Gayatri Spivak considers the "trace" in contrast to Heideggerean Being (which reproduces the logocentric, metaphysical tradition of pointing to a presence or an origin). Spivak defines the trace as "a mark of the absence of a presence, an always-already absent present" (xvii). By referring to the trace as a "mark," Spivak's definition presupposes the materiality, tangibility of the trace. For Derrida and Spivak, the trace is the absent part of a sign's presence; the trace therefore is "occulted" in the sign itself, and the trace gives the immediate impression that a signified preceded the signifier (Of Grammatology 47). According to Spivak, the trace- the French word for trace means print, imprint, track, or spoor-points to that "other which is forever absent. That 'other' is of course never to be found in its full being" (xvii). That other which is forever absent I will take to be the sublime. Moreover, signifiers (traces) point to other signifiers in an unending signifying chain; there is no ultimate referent or foundation of absolute meaning. The meaning of words (signs) differ and are deferred 
(the relationship between signifiers and signified is arbitrary), and all we are left with is a trace (the signifier), the absent presence.

In his early writings, Derrida explores the trace in terms of semiology, in particular linguistics: the meaning of a sign is absent — the signifier is a "trace" of a presupposed ideal signified. According to Derrida, the trace is neither chronological nor linear; the trace is "related no less to what is called the future than to what is called the past, and constituting what is called the present by means of this very relation to what it is not" ("Différance" 9). Derrida's conception of the trace, which incidentally he does not fully define, metamorphoses into other terms, including différance (meaning is not there and not that). Indeed for Derrida, the trace is "inseparable from the concept of difference" ("Différance" 13).

By refusing to define trace, Derrida is presumably removing himself from the logocentric, Western tradition of installing stable and fixed meanings. Furthermore, by Derridean standards, the sublime can also be understood as différance. The sublime differs/defers itself. Because the sublime symbolizes the absolute, the unattainable, meaning always differs/defers because one can never arrive at a true sublime state or ideal. The sublime is in fact a metaphysical category. The trace can perhaps never constitute a pure conduit to the sublime because the trace is self-effacing. Derrida underscores the erasure of the trace, thus highlighting the inability of achieving fixity or centeredness: "Always differing and deferring, the trace is never as it is in the presentation of itself. It erases itself in presenting itself" ("Différance" 16). Selfeffacement is built into the trace; the trace is not presence but rather "the simulacrum of a presence that dislocates itself, displaces itself, refers itself, it properly has no site, erasure 
belongs to its structure" ("Différance" 18). If the trace points to an "absolute past," (Of Grammatology 66) to a true and pure history, then the erasure of the trace bears negative consequences that may problematize interrogations of Faulkner's modernist aesthetic.

Notwithstanding, I see the trace as an arrow pointing towards the absolute-in other words, the sublime. Experiencing the trace is a teasing index of the sublime. According to J. Hillis Miller the "noun or verb 'trace' designates a mark made by or gesturing towards something pre-existing and non-linguistic that the trace points to, either back in time or forward in time" (47; my emphasis). Like Spivak, Miller considers the trace as a material, tangible object that makes its mark in the empirical world, the world of sense experience. Although Derrida never fully defines trace, one can interpret this contestable term to mean any palpable mark left by the absent thing. Robinson Crusoe's moment of de-isolation, in which he comes across Friday's footprint in the sand, exemplifies his encounter with a "trace," or with an other. The trace, according to Miller, points to a non-metaphysical, non-transcendental "wholly other" (Miller 49-50). Faulkner's literary texts, from his short stories such as "A Rose for Emily" to his major novels, contain micromoments typifying the encounter with the trace. The trace, therefore, is the absent mark that the present thing, now elsewhere, leaves behind. A footprint can be a trace, as well as an heirloom, a photograph, and other markers. Applying the theoretical concept of the absent-present trace to a literary work can focus on what the trace points to, its signification, or the larger structures of meaning that underlie the text and are revealed by its inherent contradictions (in other words, the aporia: a kind of gap in meaning). 
For the purposes of my thesis, I will interrogate palpable textual instances of the manifestation of the trace. I will liberally interpret Derrida's writings on the trace and underscore certain micromoments in which Faulkner's fictional characters encounter the absent-present trace. As I will discuss in the first chapter on "The Bear," the trace forms a pathway, a set of tracks that points to something beyond itself, that something being the sublime (whether pastoral, racial, or postmodern). In my discussions of Faulkner's fiction, I intend to underscore how the trace reminds one that sublimity is inaccessible; in other words, the trace reminds one of the failure of the imagination to capture and present the absolute, and hence the pain/pleasure dichotomy that structures the "imagination's inevitably failed attempt to present to thought an intuition that would adequately correspond to an idea of the absolute" (Johnson 120).

The trace is the absent part of the sublime's presence, a presence which is always unattainable and deferred. I will pay particular attention to moments in which Faulkner's characters experience the trace; indeed, the "cognitive failure in the face of the sublime" (Shaw 3) and the failure of language to describe the ineffable is applicable in terms of experiencing the print/track first-hand. The failure of language to describe the sublime and cognition to fully comprehend it can be seen analogously to the experience and attempt to capture what the "trace" is, its signification, and to what it ultimately points. In fact, the trace is a miniaturization of the sublime. It is its metonymic image/concept; however, the trace as well as the sublime entails a position beyond human understanding, cognition, and physical capacities. Sublimity in other words "refers to the moment when the ability to apprehend, to know, and to express a thought or sensation is defeated" (Shaw 3). The three textual works by Faulkner highlight how the encounter with the trace 
elicits similar sensations from the fictional characters who come into contact with it. Faulkner's description of the reaction to the castration-lynching of Joe Christmas, Rosa Coldfield's epistemological and semantic breakdowns at her fleeting encounter with the photograph of Charles Bon, and the encounter with the bear's maimed paw (all palpable instances of encounters with the absent-present trace) will be underscored as micromoments which embody the sublime within the context of experience (aesthetic or otherwise). These moments are symptomatic of broader aesthetic, historical, cultural, and philosophical themes prevalent in Faulkner's oeuvre. In fact, within the context of these micromoments, trace and sublime begin to mean the same thing.

The present thesis will include a chapter on each of the aforementioned texts by William Faulkner. The first chapter will deal with an analysis of micromoments in "The Bear" that reveal how the trace functions as a pathway to the sublime, as well as underscoring moments in the text in which pastoralism deconstructs itself. The second chapter will deal with a reading of Light in August and in particular the castrationlynching scene of Joe Christmas, and how Christmas exemplifies, and problematizes, the two basic characteristics of the sublime outlined by Donaldson: its elusiveness and utter strangeness and otherness. Moreover, I will emphasize how Christmas's death dissolves boundaries between whiteness/blackness (in short, the cultural institutionalization of racial difference). The third chapter, focusing on Absalom, Absalom!, will highlight how the pathway between trace and sublime is undercut by the intrusion of loss and mourning, thus ensuring Rosa Coldfield's epistemological and semantic crisis, and in turn rupturing boundaries commonly associated between self and other, mind and body, physicality and insubstantiality, knowledge and transcendence. The trace/sublime as well as other 
interchangeable terms that imply paradigms of incompletion (syncope, gap, liminal space, interstice, boundary, and limit) carries methodological and theoretical currency, aiding in the deconstruction of Faulkner's major modernist themes and underlying structures of meaning. Ultimately, Faulkner's preoccupation with the trace denotes his preoccupation with the recovery of the signified, the "meaningful" part of history, memory, and reconciliation with the past. ${ }^{8}$

\footnotetext{
${ }^{8}$ Besides the preoccupation with blood genealogies, dispossession, the link between race and identity, Patrick O'Donnell points out that the modernity of Faulkner's works "partially resides in the negotiation of an essential contradiction between a rejection of the past and the inevitable repetition of the past in that very rejection" (34). For O'Donnell, modernism represents the replacement of "outworn orders" and "old monuments" with novel, linguistic orders and "imagined geographies" that nevertheless "reproduce the structures which have preceded them" (34).
} 


\section{CHAPTER ONE}

The Pathway to the Pastoral Sublime: The Deictic Trace in "The Bear"

The pervasiveness in William Faulkner's oeuvre of the imagery of the trace- the print, footprint, spoor, or any material mark left by the absent thing after it has passed the scene of its former presence-suggests that Faulkner was cognizant of the social, historical, and philosophical dimensions of the absent-present "trace," particularly its implication as something which is past, no longer present, and entailing a sense of what history "is." Indeed the material, tangible trace (in the Derridean and non-Derridean sense of the term) is a prevalent image found in Faulkner's major works, whether in the form of an imprint, heirloom, or any object impregnated with meaning; as a result, Faulkner's notion of trace at times coincides with Derrida's theoretical construct of trace. In Faulkner's “A Rose for Emily” for example, the townspeople, curious to explore the hidden nooks of the recluse Emily Grierson's home after her death, find in a room "which no one had seen in forty years" (Selected Short Stories 58) and furnished like a bridal chamber the skeletal remains of her lover, Homer Barron. Beside the skeleton in its nightshirt lies a pillow with the indentation of Emily's head and a strand of her iron-gray hair. The vividness of the verbal details in this passage highlights the trace as the Spivakian-Derridean "mark of the absence of a presence, an always-already absent present" (Spivak xvii), as a mark pointing to an originary presence, to something that is not there. The strand of hair, moreover, is a "trace" bearing not only the configuration of 
Emily Grierson's DNA, and therefore her genealogical past, but pointing to something beyond itself, something which is literally absent and unattainable. ${ }^{9}$

The metaphorics of the trace is heavily present throughout Faulkner's 1942 novel, Go Down, Moses. ${ }^{10}$ In this novel Faulkner's refinement of the imagery of the trace begins to illuminate that the trace itself forms a "pathway" to a "something" much larger, complex, and undefinable. In "The Fire and the Hearth" Lucas Beauchamp, the black grandson of Old Carothers McCaslin, finds himself near a mound in a creek bottom trying to hide his still before he is found out by the land-and-plantation owner, Roth Edmonds, the white descendent of the McCaslin lineage. After Lucas is startled by the sound of running feet, he comes across "the print of his daughter's naked feet where she had squatted in the mud, knowing that print as he would have known those of his mare or his dog, standing over it for a while and looking down at it but no longer seeing it at all" (GDM 40). An intuitive understanding of what the trace is and what it invariably points to is a common quality inchoate in the different characters in this novel that come across the footprint, spoor, or any material trace. ${ }^{11}$

In "Pantaloon in Black" the trace begins on a literal level to form a pathway to something beyond itself. Standing motionless in the dusty lane which his late wife would

\footnotetext{
${ }^{9}$ The Derridean concept of trace has been applied to Faulkner's story by Mary Arensberg and Sara E. Schyfter in their essay "Hairoglyphics in Faulkner's 'A Rose for Emily'/Reading the Primal Trace." They argue that Faulkner's story puts forth images that "allegorize the text's quest after its own origins" (126); moreover, "all traces of 'presence' within Miss Emily's bridal chamber (the hair, skeletal remains[...]) are icons of an invisible past that has only been lived in the mind" (131). These traces "remystify the primal scene, turning it into a necrohphilic encounter" (131). In other words, there is a repetition compulsion to return to the object of desire.

${ }^{10}$ Some critics, however, consider Go Down, Moses a collection of short stories rather than a coherent novel.

${ }^{11}$ In "The Bear" Ike McCaslin will learn to distinguish the old bear's "crooked" print better than his own (GDM 199).
} 
trod on her way to the commissary, Rider, the protagonist, observes in the "pale, powderlight, powder-dry" (131) August dust the footprints of his wife, Mannie, whom he has just buried. In "Pantaloon in Black" the trace is associated on a more profound level with loss and absence, coupled with mourning over the beloved. In addition, the trace reveals the immediacy of the past, as well as the destabilizing effects of grief and memory: the "narrow, splaytoed prints of [Mannie's] bare feet," intermingled with other footprints and hooves and wheel-tracks, are "vanished but not gone, fixed and held in the annealing dust" (131). Although Rider perceives the footprints—-the trace which points back to Mannie - as fixed, stable, and noncontingent, Mannie's tracks suggest, on the other hand, the ephemerality of the trace, an ephemerality more than ephemeral. ${ }^{12}$ Most significantly, Faulkner emphasizes, beginning in "Pantaloon in Black," the track-towards or pathway formed by the trace (as footprint, imprint, spoor) and which inexorably points to an unidentifiable, albeit intensely overwhelming, space.

The trope of the trace forming a track-towards something much larger and transient than itself is consolidated in "The Bear." In the novella the trace-represented by the spoor- takes on the contours and subtleties later defined in a theoretical, philosophical fashion by Derrida, Spivak, et al. An analysis of the absent-present trace in "The Bear" therefore yields to a better understanding of the Derridean conception of trace. Conversely, and to a certain degree, the application of the Derridean trace, as a methodological and philosophical tool, leads to a deeper understanding of the multiple and sometimes conflicting discourses at work in the text. In "The Bear" the route, the gap

\footnotetext{
${ }^{12}$ As I will contend, the notion of the trace/print as a stable and noncontingent phenomenon is undermined in "The Bear."
} 
between trace and its Other becomes transparent. The trace forms a pathway to the sublime.

Therefore, the trace is always at once a trace of the sublime. The idea that the trace reveals a set of tracks that leads to the larger realm of the absolute, transcendental, even overwhelmingly intense sublime may lead to a series of questions: what does the discourse on the sublime reveal about the structures of meaning underlying Faulkner's narrative? What is the object of sublimity in "The Bear"? How can "trace" and "sublime" help one interrogate Faulkner's modernist discourse on history (or the materiality of history), the past, and pastoral in "The Bear"? In the article "Faulkner's Versions of Pastoral, Gothic, and the Sublime" Susan Donaldson explores the relationship in Faulkner's corpus between the Southern agrarian tradition and its counterpoint, urban modernism and industrialism. The same conflict is prevalent in "The Bear." Donaldson explores the two most prominent assessments of Faulkner's pastoralism: whether Faulkner's work is strongly pastoral and therefore upholds the provincial and traditional agrarian culture of the South, or whether it is antipastoral, and hence "resistant to the notion of retreating to a green world safe from the exigencies and pressures of historical change" (Donaldson 360).

Donaldson points out moments of vision and transport (ekstasis) that characterize most of Faulkner's art. Faulkner resorts to the language of the sublime in order to expose these moments of transport/transcendence and half-articulated, elusive visions (e.g., Reverend Hightower's highly personal visions in Light in August). Donaldson explores the trajectory of Faulkner's appeal to the sublime, paying particular attention to his earlier stories such as "Carcassonne" (the highest artistic ideal) and "Nympholepsy" (the erotic 
sublime) in which ambitious visions remain forever out of reach and unarticulated. ${ }^{13}$ The Sound and the Fury, for instance, is undergirded by the language of the erotic sublime, for the three brothers (Jason, Quentin, and Benjy) "strain to catch sight of and capture their ever-absent sister Caddy, whose character eludes the narrative nets cast by each of the novel's four sections" (Donaldson 365). The engagement of Faulkner's apprentice work with the pastoral sublime is indicative of his fascination with stasis and containment, and with the paradigmatization of loss and yearning implied by pastoral. Furthermore, Donaldson discusses Faulkner's aborted essay for a 1933 edition of The Sound and the Fury in which Faulkner himself dichotomizes the tools afforded to Southern writers, escape or indictment: either to indict the contemporary social scene or escape from it by retreating into a pastoral green world (gothic journey/pastoral retreat). The sublime, according to Donaldson, dominated Faulkner's art and artistic ideals in terms of ambitious visions and of failure to fully represent these visions in writing. The irreconcilable tension between pastoral and antipastoral, stasis and kinesis, representation and the unrepresentable, and trace and sublimity is disclosed in "The Bear."

"The Bear" relates the annual hunt for the larger-than-life bear, Old Ben. ${ }^{14}$ Old Ben's status as indomitable and god-like bespeaks his subtextual role as the ultimate embodiment of the Pastoral Sublime. ${ }^{15}$ For a number of weeks each year, the hunting

\footnotetext{
${ }^{13}$ The failure to achieve the vast ambition of artistic vision characterizes Faulkner's art as well; hence Faulkner's own declaration that The Sound and the Fury was his most splendid failure. According to Eric J. Sundquist, there are "limitations to [Faulkner's] vision" (qtd. in Kodat 999).

${ }^{14}$ According to Irving Howe, the hunt resembles "the tone of a religious retreat" (William Faulkner 92).

15 “The Bear" and its relation to pastoral can be summarized with the following explanation by Irving Howe: "The fable of 'The Bear' falls within the broad stream of the pastoral which courses through American writing, pastoral suggesting the conscious turn to simplicity as a desired way of life and the nostalgia for a time which could more fully realize that desire" (Howe 95). As I will show, however,
} 
party tries to hunt down the bear and put a stop to his rifling of farms, pig pens and corn cribs, livestock, and the threat he represents to the incoming lumber companies. Most significantly, the bear must be eradicated because Major de Spain, who owns part of the land, desires to sell the timber rights to the lumber companies, therefore heralding the end of the wilderness and the beginning of industrial modernism in the region. Isaac "Ike" McCaslin, the protagonist and incidentally a "nostalgic primitivist" (Bleikasten 302), comes of age among the hunting party, including: Sam Fathers, General Compson, Boon Hogganbeck, and his cousin Cass Edmonds. The story begins when Ike is ten years old as he acquires the skills of a true woodsman. Although several occasions arise in which to shoot Old Ben, Ike refuses to do so, intuitively aware of the consequences his death will have on the wilderness and by extension the green retreat offered by it.

When Sam Fathers comes across the untamed Airedale terrier, named Lion, who will keep Old Ben at bay, the expedition to hunt the bear continues with renewed vigor. After Old Ben is relentlessly pursued and finally killed by Lion and Boon Hogganbeck, Major de Spain subsequently sells the timber rights, and the Memphis lumber company begins to move in and axe the woods. Subsequently, Ike at twenty-one repudiates his heritage (the land and plantation) in an act of expiation for the guilt and sins that run in the McCaslin family. His grandfather and founder of the estate, Lucius Quintus Carothers McCaslin, has committed incest and miscegenation. Ike refuses to inherit the wrong and shame wrought by these "sins" as well as those of slavery and the despoliation of the

pastoral in "The Bear" deconstructs itself, adding multiple layers to traditional representations and interpretations of pastoralism. 
land. ${ }^{16}$ Ike believes the land belongs to no one, but must remain intact in the "communal anonymity of brotherhood" (GDM 244). The story ends with his return, at eighteen, to the wilderness one last time before it is axed away by the lumber company.

The bear, Old Ben, is arguably the embodiment of the pastoral sublime. He is synonymous with the wilderness, with its sense of antiquity and timelessness. As a matter of fact, textual evidence indicates that the bear manifests certain qualities that are tantamount to those featured in the concept of sublimity. The sense of dimensionality and transcendence attributed to the bear also constitutes the defining features of the sublime. Ike's mental projection of the bear as a monumental figure takes these qualities into account. His a priori knowledge of Old Ben prompts his idealization and totalization of the bear as the magnanimous symbol of pastoral sublimity: "It [the bear] ran in his knowledge before he ever saw it. It loomed and towered in his dreams before he even saw the unaxed woods where it left its crooked print, shaggy, tremendous, red-eyed, not malevolent but just big, too big for the dogs which tried to bay it...for the men and the bullets they fired into it" (GDM 183; my emphasis). For Ike, the bear represents the immortal and eternal wilderness; and it is in the wilderness that Ike's sense of escapism and static permanence is encompassed. Indeed the bear is "too big," and it is precisely this sense of bigness - the dimensionless "unaxed" wilderness - that Ike yearns to recover and sustain. The presence of the trace, however, problematizes this paradigm of stasis and escapism, and the green retreat, promised by pastoralism.

\footnotetext{
${ }^{16}$ According to Catherine Kodat in her essay "Making Camp: Go Down, Moses," Ike's "gesture of repudiation is a bid to free himself from his family's past, but it is also an effort to keep to himself, to evade the law of exchange" (1008).
} 
The trace, which is there and not there, does and does not lead to the bear, who is also there and not there. Before using textual evidence to demonstrate how the trace reveals a pathway to the sublime, and how this trace-presence disrupts pastoral, I wish to emphasize the moments leading to the encounter with the spoor. At first, as an apprentice of Sam Father's in woodcraft, Ike uses a compass to navigate through the woods, relying on it until he gains the skills and experience necessary to wander off by himself without the aid of the compass. He also utilizes his watch to keep track of time and his gun to hunt for game. Before initiating his quest to singularly encounter the bear (an inevitable part of his rite of initiation), Father's advises Ike to completely relinquish his gun. Subsequently, as he traverses the woods for several hours in search of Old Ben, he becomes "lost in the green and soaring gloom of the markless wilderness" (197; my emphasis), and realizes that in order to see the bear he must purge himself of both his watch and compass: "It was the watch and the compass. He was still tainted" (197; my emphasis). Ike's taintedness restricts and constricts his experiential aptitude to encounter the bear (although he will only encounter it partially, not wholly). By relinquishing these material markers of human culture, the gun (exemplifying the instrument through which conquest and land possession is secured and maintained), the compass (symbolizing distance, navigation, safety), and the watch (suggesting temporality, linearity, chronology), Ike has bereft himself of that which binds him to and keeps him within the boundaries and parameters of safety. He thus attempts to liberate himself from the confines of material culture (in this case, man-made commodities), the essential mode of being in which to experience the sublime. (At one point in the narrative, General Compson and others teach Ike to "believe the compass regardless of what it seemed to 
state" [311], underscoring the compass as a truth-telling, albeit human-made instrument, and precisely what Ike must repudiate).

Once Ike de-taints himself vis-a-vis the disengagement from these specific material objects, he is prepared to encounter the pastoral sublime in its amplitude; similarly, just as the quest for the Holy Grail, part of Christian iconography, would denote renewal, sacrifice, and reverence. That which binds Ike to human mass material culture is relegated to the background. Subsequently, as Ike wanders around in circles, half-lost in the soaring gloom of the wilderness, the narrative itself assumes a serpentine, labyrinthine syntactical structure as he ambles from one section of the woods to the other, as if textuality itself were preparing for the dizzying and disorienting sublime encounter (197-198).

After a few hours of endless searching Ike comes across a rotted log beside a swamp, interestingly in the same clearing in which Ike had left the watch and compass behind, suggesting, as Catherine Kodat does, that "where Culture was, Nature shall be" (Kodat 1009). It is during this micromoment that the trace reveals itself as the palpable imprint left behind by the hunted bear. As Ike reclines on the gutted log, he catches sight of the trace left by the maimed bear: “...seeing as he sat down on the log the crooked print, the warped indentation in the wet ground" (198). Here Ike experiences the trace, yet it is what follows which disrupts his ultimate experience of pastoral sublimity, suggesting that pastoralism always-already deconstructs itself, erases itself in the presentation of itself. Ike stares at the crooked print "[as] it continued to fill with water until it was level full and the water began to overflow and the sides of the print began to 
dissolve away" (197-198; my emphasis). ${ }^{17}$ As Ike stares ahead a set of tracks appear, forming - like an arrow - a pathway: "Even as he looked up he saw the next one, and, moving, the one beyond it; moving, not hurrying, running, but merely keeping pace with them as they appeared before him as though they were being shaped out of thin air just one constant pace short of where he would lose them forever and be lost forever himself" (198). The moment before Ike sees the bear recalls a "flash" as of lightning: "It rushed, soundless, and solidified - the tree, the bush, the compass and the watch glinting where a ray of sunlight touched them" (198). The use of metaphor in this case is apt in light of descriptions, by diverse theoreticians, of the sublime as a sudden flash of lightning. Present at the end of the tracks is the immobile, statuesque bear, waiting, serene, and observing Ike ${ }^{18}$ : "Then he saw the bear. It did not emerge, appear: it was just there" (198). Ike thus encounters the bear at a distance. ${ }^{19}$

\footnotetext{
${ }^{17}$ There are connections, despite their differences, between Faulkner's and Derrida's use of the "trace." Faulkner's use of the trace as a mark which simultaneously points to the absolute sublime but erases itself exemplifies Derrida's assumption of the "trace (of that) which can never be presented, the trace which itself can never be presented: that is, appear and manifest itself, as such in its phenomenon" ("Différance" 16). The "of that" in parenthesis, I contest, is the sublime (Derrida sees it as Being). Faulkner's use of the print/track illuminates Derrida's construct of trace and vice versa. The bear's print and the bear himself are never "presented" as such. For both Faulkner and Derrida the trace, "always differing and deferring... erases itself in presenting itself" ("Différance" 16). Because Derrida claims that trace is inseparable from différance ("Différance" 13), then it is assumed that the bear's print (as a trace) participates in the temporal/spatial process of differing and deferring the sublime object/experience. The trace, in particular due to its self-effacement, reveals the impossibility of achieving the fixity and stability of meaning granted by the sublime object/experience. In this case, "dissolve" is tantamount to "under-erasure," the selfeffacing trace. This erasure arguably reveals the past as inaccessible and invisible.

${ }^{18}$ When Ike sees the bear he "experiences an ecstasy of communion which results in his refusal to kill the animal" (Howe 94). Rather than juxtaposed to the religious sacrament, the encounter with the bear will be relocated within the domain of the sublime experience. Moreover, I see Ike's refusal to kill the bear an effect not of this particular encounter but rather because he relates the death of the bear with the despoliation of the land.

${ }^{19}$ While theorists of the sublime like Edmund Burke emphasized distance as mitigating the threat of the sublime experience (the bear is terrifying and thus, sublime; however, the beholder, Ike, isn't actually
} 
The trace/track (as a material, contingent "thing" subject to its own laws and prescriptions) points to the sublime. On the other hand, this print is under-erasure, suggesting that the absolute and absolutized bear/sublime will remain forever out of reach. All Ike can approximate is the fragment, the ephemeral print, the sublime's trace. Therefore, the encounter with the spoor mediates, but does not fully lead to, the sublime experience. The implications of the self-erasure, and Ike's refusal to accept said erasure, entail a series of ramifications and complications. The rest of this chapter will focus on these consequences.

The aforementioned micromoment — which embodies the sublime within the context of experience - suggests that Old Ben defies categorization and description, thus exemplifying Susan Donaldson's definition of the sublime as “elusive.” While Ike observes the bear, who incidentally is "fixed" and "immobile" (198) like a statue, the bear suddenly moves, breaking the stillness, crossing the glade silently and vanishing: "Then it was gone. It didn't walk into the woods. It faded, sank back into the wilderness without motion as he had watched a fish, a huge old bass, sink back into the dark depths of its pool and vanish without even any movement of its fins" $(198) .^{20}$ The doubleerasure - the print and the bear have both vanished — is suggestive of several key points. The ephemerality of the sublime moment and the impossibility of attaining the sublime

afraid of it), in this case "distance" implies that the object of sublimity - the bear-is always out of reach, an evasive vision, a Derridean "transcendental signified," an Absolute which is never recoverable or attainable.

${ }^{20}$ The juxtaposition of bear and fish is revelatory of this story's use of Christian symbolism. Christ, whose symbol is the fish/Ichthys, is unattainable except through prayer, faith, sacrifice, chastity, and ultimately a death free from sin. The bear, symbolizing the realm of pastoral sublimity, is unattainable except through these very same gestures; hence Ike's longstanding vow of chastity, his repudiation of his inheritance, and his segregationist values (see "Delta Autumn"). Or, perhaps, Ike wishes to be a fisher of men. 
object are underscored by the brevity of the scene and by the very texture of the language ("faded," "sank," "vanish," and "gone"). Most significantly, the dissolution of the tangible print relays the dissolution of hierarchies representing man and nature, nature and culture, physicality and insubstantiality, presence and absence. While the erasure of the trace suggests the fluidity of these dualisms, Ike will nonetheless continue to uphold the hierarchical structure of these binaries, participating in the logocentric, metaphysical tradition of privileging one term of the binary as superior and the other as inferior (PRESENCE/absence, WHITE/black, MAN/woman, WILDERNESS/industrial modernism, ad infinitum).

Ike thus partakes in the replication and perpetuation of these binary differences; he does not embrace the erasure of the trace. Rather, he seeks his own alternatives: he idealizes the "big woods," which incidentally are "bigger and older than any recorded document" (181), and retreats into the simplicity offered by it. He inadvertently nostalgizes the past and mythicizes the bear. ${ }^{21}$ The moment of sublimity, however (and by extension Ike's green retreat), is forever undercut by the trace under-erasure, by the evasiveness and unattainability of the sublime object of desire. Since trace/sublime imply a part/whole division, this relation implies that without trace, there is no sublime, and vice versa. ${ }^{22}$ The self-effacing print is evocative of the significance of the immediacy of the wilderness, the failed attempt to retain the static permanence offered by the wood's

\footnotetext{
${ }^{21}$ According to Derrida, however, myth has no unity or absolute source; as a matter of fact, the "focus or the source of the myth are always shadows and virtualities which are elusive, unactualizable, and nonexistent in the first place" ("Structure, Sign, and Play" 502). The bear as a mythicized figure corresponds to Derrida's idea of the myth as elusive.

${ }^{22}$ Experiencing the trace is an instance of the sublime. In terms of experience trace and sublime mean the same thing; however, the sublime is also akin to différance: the sublime always differs (not that) and is deferred (not there).
} 
"timelessness." Implicitly repudiating rather than explicitly embracing the erasure of the trace, the self-erasure implying change, socio-historical transformation, and the impossibility of retreating into an apolitical space, Ike seeks the alternative of idealizing his experience in the wilderness and inevitably retreating into "[the] impenetrable and impervious woods" (GDM 305). ${ }^{23}$

On the one hand, what Ike ultimately desires is the green retreat offered by the pastoral sublime, to immerse himself in the simplicity offered by the wilderness, to withdraw into an apolitical, ahistorical "impervious" space "older than any mill-shed, longer than any spur-line" (306), a space "not held fast in earth but free in earth and not in earth but of earth, myriad yet undiffused of every myriad part...dark and dawn and dark and dawn again in their immutable progression and, being myriad, one" (312). Ike's holistic view of the wilderness is indicative of his totalizing experience in the woods. On the other hand, if the spoor has the capacity to efface itself (thereby abrogating or removing its boundaries, limitations, confines) then the pathway between it and what it points to (the bear: embodiment and trope of the pastoral sublime) is ruptured. In other words, Ike can never fully experience the sublime by dint of the self-deletion of the pathway, the limen, the syncope. If so, Ike's emergence and integration into the wilderness — and by extension his eschewing of social realities and shunning of inheritance - holds no water. The loss of the gap, the boundary between trace and

\footnotetext{
${ }^{23}$ In "Delta Autumn," the penultimate story in GDM, Ike imagines himself and the wilderness as "coevals" and "running out together...not toward oblivion, nothingness, but into a dimension free of both time and space... where...moving again among the shades of tall unaxed trees and sightless brakes where the wild immortal game ran forever before the tireless belling immortal hounds falling and rising phoenix-like to the soundless guns" (GDM 337). This passage, among others, justifies Ike's feelings of spatial-temporal paralysis, of his desire to inhabit a space of utter simplicity free from historical/social conundrums.
} 
sublime, implies that Ike can neither fully align himself with a pastoral stance nor attain the sublime vision of transcendence through his immersion into the wilderness.

The vanishment of the bear thus precedes the vanishment of the wilderness, and Old Ben's death highlights pastoral loss and absence. Hence, immediately following the destruction of the bear, Ike glances at Sam Fathers "lying motionless on his face in the trampled mud" (229); his death follows soon afterward. If, as Susan Donaldson implies, the sublime presupposes the dissolution of meaning, the inevitability of unattainability and unrepresentability, then the erasure of the spoor implies that the history of "wilderness" is irrecoverable. In other words, the wilderness will always remain incorrigible, "axed" rather than "unaxed." Since the trace implies the omission/deferment of meaning (trace is, after all, différance), Ike cannot relocate himself within the domain of the timeless, ahistorical pastoral sublime; he is left only with the trace of the trace, continuously differing and deferring.

On the other hand, this micromoment (Ike experiencing the spoor) showcases Ike undergoing something analogous to the sublime experience. One may extrapolate Ike's sense of fear and delight, attraction and repulsion when he introspectively meditates on the nature of fear at potentially encountering the bear: "He would not even be afraid, not even in the moment when the fear would take him completely: blood, skin, bowels, memory from the long time before it even became his memory" (196; my emphasis). The sense of fear and attraction, pain and pleasure, terror and distanced safety, constitutes the extreme qualities in the sensory experience of the sublime. Ike's awareness of the potential fear resulting from the meeting with the bear prepares him to encounter Old Ben, despite the "distance" which separates him as a spectator from the sublime object. 
However, he does not prepare himself for the self-effacing print, which undoubtedly destabilizes his perspectival expectations, implicitly informing him not only of the unattainability of the sublime object, but the inaccessibility of the woods, the inability of a fixed, stable wilderness, of a green retreat into an apolitical, ahistorical domain safe from the demands of political and social change. The symbolic, metaphorical space inhabited by the bear, and which Ike "yearns to cross into" is inaccessible precisely because he "remains unable to escape his own material limitations" (Danner 272). Hence the presence of the compass and watch during his encounter with the bear.

In section five, when Ike returns to the camp one more time before the lumber company moves in to cut the timber, Ike believes he can reject the rampant industrialization occurring around him by peering into the "wall of wilderness ahead within which he would be able to hide himself from it once more anyway" (303; my emphasis). ${ }^{24}$ Ike's immersive escapism is self-generative and solipsistic. As a matter of fact, Patrick O’Donnell calls Ike's anguish over the loss of the wilderness "narcissistic despair" ("Faulkner and Postmodernism" 38). Ike's rejection of social-historical change is akin to his rejection of the self-erasure of the trace which he should otherwise embrace. ${ }^{25}$ In terms of Ike's repudiation, Faulkner's stance might be largely antipastoral,

\footnotetext{
${ }^{24}$ Many critical scholars, such as Catherine Kodat and Richard Godden, have noted the relationality between John Keats's "Ode on a Grecian Urn" and "The Bear." Both the poem and the novella are divided into five sections, each section of the poem corresponding to its counterpart in the novella. Keats's poem undoubtedly serves as a template for Faulkner's discourse on the sublime, stasis, permanence, and the woods' immutability fronted by Ike's idealized nostalgia for lost origins. As Bruce Danner has pointed out, the bear is compared with Keats's "foster-child of silence and slow time." Ike, therefore, wishes to literally "slow time."

${ }^{25}$ According to Patrick O'Donnell, GDM is a transitional work which "oscillates between tragic nostalgia for a lost past of certain, integral origins and the parodic embracing of an indeterminate future in which identity is aggregate, mixed" ("Faulkner and Postmodernism" 32; my emphasis). Ike immerses himself in the timelessness offered by the wilderness, while the trace under-erasure reminds - or threatens - him with
} 
and his view of history, contrary to Ike's outlook, is one of dialectical progression along a diachronic (horizontal) line. In "The Bear" pastoralism is always self-contradicting. The mutability and transformative power of trace, language, identity, the wilderness, and the world is abjured by Ike's reactionary, orthodox frame-of-mind: "They [the woods] did not change, and, timeless, would not, any more than would the green of summer and the fire and rain of fall and the iron cold and sometimes even snow..." (307). Ike's certainty of the wood's timelessness is indicative of his yearning for a perpetual green retreat, his attitude of escapism, and overall his valorization of presence over absence.

In order to underscore his umbilical relationship with the wilderness, Ike considers the woods his "mistress and wife" (310), and the ostensibly gendered and sexualized woods offer him the necessary solace from increasing urbanization and industrialization — the social phenomenon Ike refracts by hiding in the "markless wilderness" (197) ${ }^{26}$ The tension between the markless wilderness and the threat of industrialism, which will "mark" or "taint" the wilderness, is heightened at certain points in the narrative, such as when the bear is compared to a locomotive: "It seemed to him that he could actually see...the bear too: the thick, locomotive-like shape" (225). This particular juxtaposition, like the juxtaposition between the bear and the Ichthys, deserves at least a passing glance. The bear-locomotive symbolizes the narrative's multiple (and sometimes contradictory) discourses, in particular the conflict between — and integration of - the wilderness and industrialization, urbanity vs. rurality, and the negotiation between history and the present, between provincial agrarianism and urban modernity.

\footnotetext{
the potential multiplicity (“aggregate", "mixed”) of identity. Ike's frame-of-mind would disallow this multiplicity.

${ }^{26}$ Indeed this "intimate, originary relation to the land" (O’Donnell 36) justifies the eroticized vocabulary.
} 
The bear-locomotive ruptures the boundaries between the nature/culture opposition, contradicting Ike's own "mapping," through his mythologizing of the wilderness, "of binary differences between animal and human, primitive and civilized, black and white" that inevitably enunciates the "content of racial stereotypes" (O'Donnell 36).

The metaphorical image of the bear-locomotive, I contend, reveals Faulkner's modernist fascination with the struggle between historical paralysis and historical continuity. Faulkner arguably exposes the rupture of historical paralysis through this paradoxical image; in other words, Faulkner seems to state, to borrow a now-famous quote from the film The Leopard, that "For things to remain the same, everything must change." Regardless of the change surrounding him, Ike visits the graves of Sam Fathers and Lion, and, looking for the bearings on the trees nearby their graves, comes across a tin box nailed to the tree above Lion's resting-place, holding as its violent content "Old Ben's dried mutilated paw" (312).

The dried paw represents the desiccation of the pastoral sublime, brought about by the destruction of both the wilderness and Old Ben. On the other hand, the bear is memorialized through its desiccated paw inside the tin can. The aesthetic halo previously surrounding the bear — as if it were a relic or an art object—is presently dried, shriveled. It is during this moment where one finds a slippage in the text, a point in which irreconcilable positions cannot be brought together into a smooth meaning. The present thing (the paw) is contained inside the malleable and ductile metal, tin, and in a way tin is both destructive and constructive for the pastoral sublime. The tin can functions as a metonymic image representing commodification, symbolizing (and rhyming internally with) the growing lumber company, its new planning mills, the axing of the woods, and 
the stack of "steel rails red with the light bright rust of newness" (302; my emphasis) Ike beholds while boarding the log train that will take him into the section of the as-yet "unaxed" woods. Tin also symbolizes the metallization of the wilderness and by extension, Old Ben; the mechanization and reification, in fact, of the wilderness and pastoral sublimity. ${ }^{27}$ On the other hand, this ductile, human-manipulated crystalline metal is a viable image for preservation, for tin, when used to coat other metals, prevents corrosion. The tin can metonymically disrupts pastoral, but simultaneously prevents its corrosion. $^{28}$

While Ike has adopted the idealism of pastoral as an alternative way of life, he tries to maintain the totality of his experience in the wilderness by relying on the mutilated paw, by his belief that "Old Ben too, Old Ben too; they would give him his paw back even" (313). The ending of "The Bear," however, offers an image of fragmentation and multiplicity that functions as a counter-narrative to Ike's essentialist discourse on the immortal wilderness. The sense of fragmentation - the plurality of meaning — is also suggested by the print under-deletion. After contemplating the shriveled paw, Ike makes his way through the woods, hearing a sound "as though someone were hammering a gunbarrel against a piece of railroad iron" (314; my emphasis). The third-person narrator's

\footnotetext{
${ }^{27}$ Thus the transmogrification of the wilderness into an industrial landscape.

${ }^{28}$ My discussion of Faulkner's use of metonymy/synecdoche draws attention to David Lodge's essay "The Language of Modernist Fiction: Metaphor and Metonymy." Lodge argues that the modernist novel assumes a metonymic style that "serve[s] the purposes of metaphor" (491). Modernist authors, like Faulkner, invest their prose with a "metaphoric meaning beneath the metonymic surface." (492). For Lodge, the figure of synecdoche is "closely associated" (483) with metonymy; Faulkner's use of synecdoche (the bear's paw standing for the whole: Old Ben, representative of pastoral sublimity) follows the same logic as the use of the tin can to metonymically suggest the imminent arrival of industrial capitalism.
} 
deployment of metallic imagery taunts/sympathizes with Ike's sense of loss and nostalgia, prompting him to consider the imminent destruction of the wilderness and the beginning of the age of industrial machinery. Subsequently, he comes across a frantic Boon Hogganbeck hammering his gun-barrel against the gun-breech, while myriad squirrels scurry across the clearing. Boon's frantic demeanor denotes the aftereffect of having dethroned the representative of pastoral sublimity. The fragments of Boon's gun lay scattered around him, and as Ike approaches Boon, he frantically yells: "Get out of here! Dont touch them! Dont touch a one of them! They're mine!" (315).

The suggestive image of fragmentation (fragmented objects will also play a key role in discussions of the plurality of meanings found in Light in August and Absalom, Absalom!) reveals the playful impossibility of attaining the whole (or what Ike refers to as oneness [312]). Ike's mental projection of the wilderness as a tenable ahistorical, apolitical space is undermined by this image of fractured impossibility. This fractured impossibility functions both as a corollary and a solution to the trace under-erasure. One cannot attain the sublime; one can barely attain the trace; meaning is always broken and fragmented.

Since Ike rejects the social phenomena in which he is circumscribed, instead fostering his transition into an ahistorical, immutable space, he in effect (and in contradiction with his values of nostalgia for lost origins) denies the past, denies time influx. In order to better understand how Ike melancholically rejects/represses the past, and how the bear evokes it, I will relocate my arguments within the domain of monumental studies. Old Ben can also be depicted as a monumental figure that subsequently 
transitions into a counter-monumental one, evoking the immediate past. ${ }^{29}$ In monumental studies, the monument, which evokes linearity, stands in for an urge to forget, while the counter-monument stirs up (and works to) memory, disrupting the totality of the monument and notions of linear time. ${ }^{30}$ The anti-monument, on the contrary, denies the past and tries to hide it. ${ }^{31}$ Early in the narrative Old Ben is depicted as a monument: "it was just there, immobile, fixed in the green and windless noon's hot dappling, not as big as he had dreamed it but as big as he had expected, bigger, dimensionless..." (198; my emphasis). The adjectives here serve to heighten the bear's monumental stature. Ike's monumentalization of the bear and the idealization of the wilderness it inhabits serves his enterprise: to project and subsequently retreat into an atemporal, ahistorical realm free from the demands of historical, political, social, indeed cultural, transformations.

Since "monumentality severs the past from the present" (Luciano 35), Ike willingly monumentalizes the bear, as the bear transmits, for Ike at least, a narrative predominated by the "timelessness" of the woods' unchanging, noncontingent state. If the bear for Ike stands as a monument, then the bear-monument represents forgetfulnessexactly what Ike wishes to achieve. According to Dana Luciano, the monument "attempts to stop time... enshrining a located and particular interpretation of an event's or individual's significance as universal and timeless" (Luciano 35). In consequence, Ike functions as a monumental character in his attempt to stop time and for "enshrining" a

\footnotetext{
${ }^{29}$ In contradistinction to Irving Howe's "totemic" bear. For Howe, Ike can keep alive the memory of the totem (A Critical Study 94).

${ }^{30}$ I am using as a template Dana Luciano’s essay “Melville's Untimely History: 'Benito Cereno' as Counter-Monumental Narrative.” Luciano describes the monument, which elides cause and underscores effect, functioning as "an ahistorical sign of history" (35).

31 According to Luciano, the anti-monument "....rather than desacralizing the power of the past...melancholically denies it" (37).
} 
particular and personalized view of the wilderness as a self-contained, disinterested, immutable, and apolitical space. Ike arguably confuses the bear's counter-monumental function with his monumental stature. Moreover, further textual imagery evokes the bear's apocryphal status as a monument. The bear is at times depicted as a statue; he is described as "absolved of mortality" (183); he is compared to Priam; and in the novella's fourth section (itself a trace of a larger genealogical network), Cass McCaslin reads John Keats's "Ode on a Grecian Urn," associating the bear with the "she [who] cannot fade" (qtd. in 282) described in the frieze. ${ }^{32}$ The bear, however, is counter-monumental (it achieves its counter-monumentality in particular through its shriveled paw), and contrary to Ike's predominant view, the dried paw counters his valorization of stasis. It is when the bear is miniaturized into the dried paw, when the Grecian urn metamorphoses into Uncle Hubert's "tin" coffee pot, when the woods are axed by the lumber company and become the mills and railroads, when the fragments of Boon's gun lay scattered around him, that Ike's attempt to stop time is always undercut. Kinesis unfortunately catches up with Ike's campaign on stasis. More than a monumental character, Ike functions as an antimonumental narrator. ${ }^{33}$

Ike's internalized feelings of escapism and his repudiation of growing industrial social realities invariably leads to his projection of the bear, and by extension its kingdom

\footnotetext{
${ }^{32}$ In fact, when Boon and Lion hurl themselves at Old Ben during the final "battle," Lion at his throat and Boon lunging his knife into the bear's heart, they three for an instant "resembled a piece of statuary" (228; my emphasis). This image stresses the monument's emphasis on a static, atemporal form. The bear-statue struggling against Lion and Boon resembles Laocoön and His Sons. During another point in the narrative, the bear is "reliefed against [the wilderness]" (181).

${ }^{33}$ The melancholia attributed to the anti-monument corresponds with Ike's nostalgic melancholy for a lost past of stable origins. I contend that Ike is an anti-monumental character because he denies the past, seeking to entrench his values, ideals, and even his corporeality into the mythic woods.
} 
(the wilderness), as a monument. On one hand the monument can cushion and numb, disconnecting individuals from history; therefore, the bear must become a countermonument by way of the dried paw, an object that negotiates the way history is represented. Ultimately, the self-effacing trace discloses the impossibility of achieving the sense of fixity implied by the monument. Most significantly, the changed and changing trace posits the valorization of kinesis over stasis, of absence over presence. For instance, the silver urn filled with gold coins - Ike's monetary inheritance-described in section four is morphed into a "tin" coffee-pot stuffed with a plethora of IOUs; this image among others continuously undermine the text's presumed valorization of stasis and rather posits the joyful inevitability of kinesis, change, and immanence. ${ }^{34}$

Faulkner's reliance on metonymy and synecdoche contributes to the disruption of STASIS/kinesis, of (historical) PARALYSIS/continuity. Derrida, for instance, acknowledges the "disappearance of the trace of the trace" ("Différance" 17), and this dissolution of synecdochical traces is manifested in "The Bear"- the trace dissolves, the bear dissolves, the woods dissolve. The print stands for the bear, the bear stands for the woods, and the woods or wilderness for the Absolute Sublime, of timeless transcendental truths and unmediated, stable meanings. Both Derrida and Faulkner were aware of the erasure of the trace of the trace; print, bear, woods-all erased.

Notwithstanding, the bear's print (the signifier) never leads to the bear (the signified); this phenomenon exemplifies Derrida's idea that the signifier never leads to the extra-linguistic signified, but rather to other signifiers (hence the dried paw, the

\footnotetext{
${ }^{34}$ Bruce Danner, in his article "Epic Tears: The Dislocation of Meaning in Faulkner's 'The Bear"” describes Uncle Hubert's coffee-pot functioning "as a failed metaphor of Keats's urn and its transcendent significance" (271).
} 
sacred script of the commissary ledgers, the coffee-pot, and any other signifier substituted by other signifiers in a chain of substitutions). Because a signifier is playfully substituted by other signifiers inside the structure of language, the bear's spoor is replaced by other signifiers (the desiccated paw, for example). As Spivak posits, a "sign will always lead to sign, one substituting the other (playfully, since 'sign' is 'under erasure') as signifier and signified in turn" (xix). Faulkner was cognizant of the playfulness and unending polysemic "differences" that constitute "sign," although he locates his narrative within the domain of the sublime, as an "other," to quote Spivak, "never to be found in its full being" (xvii).

Other traces of the bear are left behind after he has passed the scene of his former presence. Old Ben, the dethroned king, the monument-now-counter-monument, makes his final "mark," the excoriations on Boon Hogganbeck's face, a swipe from the bear's claws, and which "resembled crusted tar in the sunlight" (239). The trace may exist in the human body as an inscription, another metonymy/synecdoche through which the bear "speaks." Boon has dethroned the king, and the price he pays is the permanent scar left by the Transcendental Bear. ${ }^{35}$

The significance of the presence of the trace is to reconcile the past and history, in particular the destruction and despoliation of the natural world populated by both man and animal. Yet Ike's "reconciliation" leads to a rupture in the text; instead of offering resistance within the modernizing, industrial milieu, Ike completely shuns it. He does not

\footnotetext{
${ }^{35}$ According to Bruce Danner, Old Ben's association with the "image of permanence and immutability [and] transcendence" is "belied by the animal's vulnerability and death" (Danner 290).
} 
live within it but outside of it. ${ }^{36}$ In other words, he works to provoke a forgetfulness and inertia that is irreversible. Ike nostalgizes the past and rejects modernization, views not held by Faulkner himself: "There is no nostalgia for the past in Faulkner. The modern world overwhelms a society that deserves to collapse" (Fargnoli 83). ${ }^{37}$ Similarly, as Catherine Gunter Kodat has pointed out, Ike's repudiation “may actually perpetuate the conditions it aims to abolish" (1026). Ike's alternative is to uphold the playfulness of fragmented and broken meaning, of the plurality offered by a trace always-already erased.

"The Bear" is a text that transgresses its own boundaries, playing with its own multiple, conflicting discourses in order to deconstruct and subsequently reconstruct a new layer of meaning upon it. In this chapter I have tried to argue the following: (1) that the contingent trace reveals a pathway to the sublime, the trace and the sublime symbolized respectively by the bear's spoor and the bear himself (who is synonymous with the timeless and immutable wilderness); (2) that pastoralism deconstructs itself in "The Bear" and that the self-effacing trace undermines both the conditions for the possibility of achieving pastoral sublimity and the notion of an absolute past; (3) the impossibility of Ike's retreat into an ahistorical, apolitical space represented by the dwindling wilderness.

\footnotetext{
${ }^{36}$ Patrick O'Donnell makes a significant observation in his article "Faulkner and Postmodernism." According to O'Donnell, Faulkner may be suggesting that the values expressed (whether implicitly or explicitly) by Ike, "values in which segregation, ahistoricity, anticapitalism, and identity formation," which "are so twisted up together that it is impossible to separate them," may be outmoded themselves (O’Donnell 42).

${ }^{37}$ According to O'Donnell, the fictitious, linguistic world of Yoknapatawpha (among other linguistic realms forged by modernist writers) "replicate[s] the past even as [it] represent[s] the ethereal attempt to break free of it" (33).
} 
Old Ben, the figurative pastoral sublime, is like the ever-absent Caddy, like the fleeting nymph in "Nympholepsy," like the elusive aesthetic visions in "Carcassonne." Old Ben is pursued but literally and figuratively unattainable. ${ }^{38}$ The trace mediates but does not fully lead to the sublime experience, suggesting several points: the binary systems Ike tries to reproduce are recognizably fluid, unstable, and contingent. The deleted trace also reveals the slipperiness of fixed meaning and a "past that has never been present"; in other words, an absolute past ("Différance" 15). The trace, however, may assume different material forms. In Light in August, the dark smears of Joe Christmas's blood (which adds a gothic dimension to the current discourse) will subsequently become the focal point of trace. I have interpreted the trace/path liberally, and therefore my analysis is/is not necessarily Derridean, but more thematically constructed.

\footnotetext{
${ }^{38}$ Before encountering Old Ben, Ike juxtaposes his thoughts about having to see the bear ("So I will have to see him" [193]) with entering the room of a woman "who has loved and been loved by many men" (193). Hence Bruce Danner declares that Old Ben is compared to the figure of a prostitute: "Like the bear, the prostitute occupies a space of male pursuit" (Danner 284). On the other hand, Danner states elsewhere that the bear is hermaphroditic, for the text describes Old Ben as "unwifed", "childless" and "its own ungendered progenitor" (qtd. in Danner 287).
} 


\section{CHAPTER TWO}

(T)race and Crypto-Genealogies in Light in August

"Just when do men that have different blood in them stop hating one another?"

- Joe Christmas

The trace may also be solicited within the context of race and blood genealogies.

In the novella "The Fire and the Hearth" Lucas Beauchamp feels an unwavering sense of pride in the "composite of the two races which made him" (GDM 101), and his certainty and affirmation of his "white" and "black" blood carries him throughout the novella and into Intruder in the Dust. Beauchamp's genealogy is unquestioned-his parentage is clear and well-known; hence his acknowledgement of the intertwining black/white races which constitute his social and racial being. In Light in August, however, Faulkner presents a character, Joe Christmas, who is the antithesis of Beauchamp for the simple reason of the uncertainty surrounding his true parentage, his supposed "black blood," and the morass of his genealogy. While Lucas resolutely accepts his mixed racial heritage, his compositeness, Christmas on the other hand ambiguously defers and deters his acceptance of it, although, as I contend, there are slippages in the text which suggest otherwise. $^{39}$

Whereas I have inquired into the nature of the Pastoral Sublime in "The Bear" and the function of the trace as a pathway to the unattainable and disorder-generating sublime, I will now relocate the focus of "trace" within the context of race and the racialization of blood, all in the purview of the "dark" sublime, in Light in August. Susan

\footnotetext{
${ }^{39}$ According to Faulkner, Joe Christmas is a tragic figure who "didn't know what he was and would never know; and that to me is the most tragic condition that an individual can have- to not know who he was" (qtd. in Fargnoli 38).
} 
Donaldson's model is an adequate schema for the inquiry into how the sublime relays a radical encounter with alterity. ${ }^{40}$ For Donaldson, the sublime is characterized by both its (1) elusiveness, and (2) its utter strangeness or otherness. These characteristics inherent in the sublime will allow for a discourse on otherness, and in particular race and genealogy. Therefore, I will underscore the text's conscious or unconscious use of imagery that ruptures the boundaries defining the binary opposition whiteness/blackness ${ }^{41}$ and that subsequently posits these two terms as, to use Ike McCaslin's terminology, "coevals."

Light in August begins with Lena Grove, a "country gal" from Alabama who has been searching for the missing father of her unborn baby, presumably to wed him before the child is born. She journeys to the town of Jefferson after she hears he has been working there in a planer shed. Lucas Burch (alias Joe Brown), the father of the unborn child, has indeed been working in the planer shed, meanwhile bootlegging on the side with his business partner, Joe Christmas, a "racially ambiguous" character (Donaldson 362). Christmas, who may or may not be part-black, spends his early years in an orphanage, and at the age of five is adopted by the strict and draconian Calvinist McEachern, who relentlessly forces his religion onto him. At a dance with his girlfriend, Christmas is confronted by McEachern; Christmas crashes a chair over him and leaves him unconscious (and apparently dead). After years travelling through "a thousand savage and lonely streets" (220) he finds himself in Jefferson, Mississippi, where he begins to work in the planer shed shoveling sawdust, and selling whiskey to a few

\footnotetext{
${ }^{40}$ Donaldson considers Light in August a "composite" of pastoral comedy and gothic nightmare (“Faulkner's Versions" 360).

${ }^{41}$ Or in Yoknapatawpha County's social view, WHITENESS/blackness.
} 
discreet clients. He lodges in the "Negro cabin" nearby the home of the New Englander Joanna Burden, and afterwards becomes her lover.

After Burden attempts to shoot him with a Civil War cap-and-ball pistol, Christmas slashes her throat and sets the house on fire. After he is caught in Mottstown (20 miles from Jefferson), his grandmother, who has not seen him in over 30 years, and his grandfather, who preaches the superiority of the white race and in consequence the lynching of his own grandson, head over to Jefferson and seek the help of Reverend Gail Hightower. Hightower is an ex-minister who suffered a scandal years before, and indifferent to the town's request, refused to leave Jefferson, plagued by visions of a wartime cavalry raid (his grandfather among the raiders). Subsequently, Christmas escapes (oddly after he decides to plead guilty and accept a life sentence) and seeks refuge in Hightower's house, but he is ultimately lynched. His whiskey-selling partner, Joe Brown (Lucas Burch), leaves Jefferson for good after he confronts Lena. The novel ends on a comic note, with Lena and her "meek Joseph" (Bleikasten 277) Byron Bunch—who also worked in the planer shed—on a fruitless quest to find Burch.

The terse synopsis may lead to a number of questions: What material "thing" constitutes the trace in Faulkner's novel? Moreover, what does the trace point to? How is the sublime associated with otherness and blood genealogies? Focusing on the absentpresent trace (Joe Christmas's composite blood) and what it points to (an indefinable genealogy impossible to categorize and map) will allow for an understanding of race and race relations in Light in August, and how the elusive Christmas unsettles a prescriptive society's rigidly-installed hierarchical oppositions (such as WHITE/black). Indeed, Joe Christmas is a marginalized Other who cannot articulate his difference and his alterity. 
He can only half-way articulate his difference. The present chapter will focus primarily on the scene of his lynching-castration — not without alluding to other major instances in the novel—to show how: 1) slippages in the text reveal Joe Christmas "performing" or "speaking" both whiteness and blackness, thus suggesting the fluidity of racial boundaries while also positing Christmas as a composite, heterogeneous character not easily defined or contained; ${ }^{42}$ 2) how Christmas, especially at the time of his death, exemplifies a radical encounter with otherness and difference; and how 3) Joe Christmas disrupts pastoral images and associations with the intrusion of a "dark" or "racial" sublime. In Light in August, I contend, the trace emerges as the black smears of Christmas's blood, and this racialized blood points to a larger, more complex genealogy that defies definition, categorization, and the finality of stable, reliable meanings. ${ }^{43}$ I will argue that the death of Joe Christmas (and his so-called tainted blood) dissolves the boundaries between whiteness and blackness, positing, rather, their consubstantiality. Joe's ambiguity surrounding his own race (he is not sure whether he is in fact both white and black) both installs the binary opposition white/black and apparently subverts it.

Just as I have synoptically delineated the moments prior to Ike McCaslin's encounter with the spoor in "The Bear," so I will focus momentarily on the narrative

\footnotetext{
${ }^{42}$ Despite Faulkner's (sometimes modern, sometimes reactionary) politics concerning segregation, integration, miscegenation, and other racial issues. According to Nicholas Fargnoli and Michael Golay, "Faulkner's attitudes on white and black relations...were complex and profoundly ambiguous" (83). While Faulkner was "deeply troubled over the South's racial past and present," (Fargnoli \& Golay 84) Faulkner nevertheless managed to manifest contradictory attitudes regarding race. Faulkner's foray into racial politics included outspoken condemnation of the Emmet Till murder, his endorsement of gradual integration, and a general promotion of civil rights for blacks. On the other hand, he sometimes retracted from these social-political standpoints.

${ }^{43}$ The black smears of Joe's blood suggest the obscurity of his racial identity and genealogy (indeed, the sublime entails obscurity and secrecy).
} 
events immediately preceding the emergence of the trace/sublime. The chapter in which the trace emerges (chapter 19) is divided into two sections. The first section begins with a flash-forward in which Gavin Stevens, Jefferson's district attorney, converses with his Harvard-graduate friend, expounding to him the motives for Christmas's actions. Christmas, Gavin speculates, must have taken heed of his grandmother's last resort: to seek refuge and sanctuary in Reverend Gail Hightower's home. Stevens relates how a shackled Christmas, escorted by a deputy and a large mob of onlookers, escapes suddenly from among the crowd and runs toward Hightower's secluded home (he lives in an unfrequented area of town). As Stevens wonders why he chose the Reverend's house as his last hiding-place, his speculations and philosophical inquiries inevitably turn to the issue of race and, in particular, the distinction between Christmas's white blood and black blood. $^{44}$

Peculiarly enough, Stevens has a deeper, albeit flawed, understanding than most members of the community about codified patterns of thought, with how white blood is distinguishable from black blood in terms of behavior. Stevens juxtaposes Christmas's escape from the crowded square to his metaphorical retreat from his past, his heritage, his genealogy: "But there was too much running with him... Not pursuers: but himself: years, acts, deeds omitted and committed, keeping pace with him” (448). Moreover, Stevens recognizes that white communities justify their collective fear and negative attitudes toward the other (in particular the "black" other) by projecting a "taint" upon

\footnotetext{
${ }^{44}$ According to Judith Bryant Wittenberg in her essay "Race in Light in August: Wordsymbols and Obverse Reflections," Stevens's discourse "offers a biological explanation for Joe Christmas's unfortunate behavior" (147); however, Stevens's explanation is deemed reductive and "inadequate to the nature of events and character as represented" (147). Moreover, there is an element of nefariousness to this notion of "black" or "white" blood (Wittenberg 147).
} 
that other; this "taint" rests on the racialization (and ultimately the sensationalizing) of Christmas's blood and body. Stevens underscores the "stain" that has been "put...either on his white blood or his black blood, whichever you will, and which killed him" (448).

Stevens's discourse on white and black blood sets the two racially and culturally constructed terms in a dialectical relationship. Whereas white blood is ratiocinative and follows social convention, black blood implies viscerality, impetuousness, the primordality of base human nature:

But his blood would not be quiet, let him save it. It would not be either one or the other and let his body save itself. Because the black blood drove him first to the negro cabin. And then the white blood drove him out of there, as it was the black blood which snatched up the pistol and the white blood which would not let him fire it. And it was the white blood which sent him to the minister, which rising in him for the last and final time, sent him against all reason and all reality. (449)

Stevens's use of essentializing terminology to assess "blood" in its biological, racial sense reinscribes the opposition WHITE/black in its Westernizing, totalizing framework. The incantatory repetition of "blood" (a total of six times in the aforementioned passage) is representative of the supposed linkage between blood and pre-determined behavioral modes. In fact, it is Joe's "black blood" which leads to his undoing; the tumultuousness of the two contending bloods in a self-appointed pariah prompted his final actions: "It was the black blood which swept him by his own desire beyond the aid of any man... And then the black blood failed him again, as it must have in crises all his life" (449). According to the district attorney, Christmas defies his black blood moments before his death. It is arguably this defiance of black blood (or white blood, whatever the case may be) that is indicative of his attempted repudiation of his otherness, his difference. Christmas exists either as a white man or as a black man; from Stevens's point of view, 
Christmas refuses to negotiate his blackness and black blood. What Stevens - perhaps unconsciously—intimates is that Christmas exists in a "middle distance" between whiteness and blackness.

Contrary to Stevens's beliefs, Joe is able to articulate and negotiate his difference and blackness through his death, through the expulsion of his pent black blood. The second section of chapter 19, in which Christmas is violently lynched, is a flashback to the events leading to his escape from the crowded square. The moment Joe is lynched is the "micromoment" in which the trace (indeed, [t]race) emerges as Joe Christmas's "stained" black blood. The section begins with a small biography of Percy Grimm, the captain in the state national guard who forms a platoon in order to keep law and order present in Jefferson during Christmas's indictment. Grimm is an egregious white supremacist (according to Grimm, the white race in America is superior to all others) and a keen nationalist. ${ }^{45}$ After Christmas escapes, Grimm relentlessly tracks him down and, accompanied by several men, rushes into Hightower's house where Christmas has hid and shoots him in the kitchen as he crouches behind an overturned table.

Subsequently, those who accompanied Grimm "saw the table flung aside now and Grimm stooping over the body" (464). With a butcher knife, Grimm castrates Christmas. Through the act of castration, Grimm not only intends to emasculate him, but rather to, in his own words, "Let women alone, even in hell" (464). ${ }^{46}$ As the men approach Grimm

\footnotetext{
${ }^{45}$ Indeed, racial segregation and white supremacy, according to Judith Wittenberg, "were ingrained patterns in Southern thought" and these patterns became "increasingly codified after World War I" (148). Interestingly, Grimm despises his parents because he was born too late and therefore could not partake of the war (Light in August 450).

${ }^{46}$ Joe's castration implies that he is now an androgynous figure, one who implies a subversion of binary oppositions (whether male/female, white/black, lynchers/lynched), a figure who is not that and not there.
} 
and Christmas, their reaction is filled with horror and abjection: "When they approached to see what he was about, they saw that the man was not dead yet, and when they saw what Grimm was doing one of the men gave a choked cry and stumbled back into the wall and began to vomit" (464). Their reaction to Joe's lynching-castration is a combination of horror and sublimity — the visceral ugliness and grotesqueness inspires dread in the onlookers. They are experiencing the terrifying abjectness of the dark sublime. $^{47}$

As a still conscious Christmas looks up at his lynchers, his "face, body, all, seemed to collapse, to fall in upon itself, and from out the slashed garments about his hips and loins the pent black blood seemed to rush like a released breath" (465; my emphasis). This passage depends upon images that influence a certain liberatory effect—Joe's body, like a wall that previously served as a barrier or impediment, "collapse[s]" and "fall[s] in upon itself," suggesting that he is achieving a radical sense of singularity and physical freedom associated with death. The liberating explosion of his blood signifies the enunciative moment in which Christmas can finally negotiate and articulate his blackness and otherness, his fragmentary identities. ${ }^{48}$ The bursting forth of the black blood from his pale body represents the dissolution of boundaries normally defining the opposition white/black: "It seemed to rush out of his pale body like the rush of sparks from a rising rocket; upon that black blast the man seemed to rise soaring into their memories forever and ever" (465; my emphasis). He is finally liberated - hence the rocket analogy-from

\footnotetext{
${ }^{47}$ In this case abjection, the prodigious emergence of uncanniness, is akin to the sublime.

${ }^{48}$ According to Deborah Clarke, "Joe's transcendence appears to rest on the obliteration of race as he becomes simply a man" ("Gender, Race, and Language" 412); however, she points out, his castration "obliterate[s] gender" (412).
} 
strict (Southern) social categorizations and racial codifications. The analogy between the rush of his black blood with the rush of sparks from a rising rocket not only highlights the feeling of emancipation from what Judith Wittenberg describes as "the human need for classificatory ordering in the social world, [and] the human tendency to categorize" (150; 163), but also stresses the sense of amplitude and physical freedom associated with the sublime experience. Joe's death is depicted as a sublime spectacle; the raw viscerality of this scene, its dark and nauseating sublimity, underscores its paradoxical nature, for it is conveyed second-handedly (just as the scene in which Rider, from "Pantaloon in Black," pounds his jailers is caricaturized and conveyed as cartoonish by the sheriff).

The verbal language used to describe Joe's death also suggests that any attempt to capture him is always undercut; language/textuality remains ineffable in its attempt to fully define Joe Christmas. ${ }^{49}$ Although Joe defies definition and categorization, he is alternatively memorialized (like Old Ben). The closing commentary following the soaring of Christmas into the memories of his lynchers underscores the (Wordsworthian) recollection of the dark sublime in a state of tranquility; Christmas, in fact, becomes a counter-monumental figure that stirs up his lynchers' memory: "They are not to lose it, in whatever peaceful valleys, beside whatever placid and reassuring streams of old age, in the mirroring faces of whatever children they will contemplate old disasters and newer hopes" (465). All that will remain with them is the trace-memory of Joe's horrific and abjection-inspiring death. Joe's death becomes an injunction, not unlike King Hamlet's plead, to remembrance: "It will be there, musing, quiet, steadfast, not fading and not particularly threatful, but of itself alone serene, of itself alone triumphant" (465; my

\footnotetext{
${ }^{49}$ Thus Christmas "eludes the narrative itself" (Donaldson 370). Donaldson refers to Christmas as a specter who haunts the pages of Light in August and "the collective imagination of its white characters" (368).
} 
emphasis). Lack of any real physical threat, the sense of serenity and triumph, and the ineradicable impression of his black blood are features that signify the sublime experience. Most significantly, Christmas's blood (the trace) points to a more obscured and indefinable genealogy (the "dark" sublime) that no one in the text can in fact fully define. ${ }^{50}$ Indeed, his lynchers counter-monumentalize Christmas through the intricate and indelible workings of memory. Joe's death is a veritable instance of the sublime.

Numerous narrative moments and images in Light in August consolidate what Joe Christmas's abjection-generating death intimates - the eruption of the binary difference between whiteness and blackness and the erasure of boundaries which demarcate race(s). The rest of this chapter will focus on the palpability of these moments. Christmas is a character who defies representation and classification - he is, on the contrary, positively indeterminate, irreducibly plural. This sense of the plurality of identity keeps Joe from achieving a racially fixed, monolithic form. As Christmas, who has been living in a Negro cabin near Ms. Burden's “dark house," reclines in his cot after a day of labor shoveling sawdust (and selling whiskey), he suddenly hears a multiplicity of voices: "Then it seemed to him, sitting on the cot in the dark room, that he was hearing a myriad sounds of no greater volume - voices, murmurs, whispers: of trees, darkness, earth; people: his own voice..." (105). ${ }^{51}$ These primal, earthy voices are not only suggestive of Christmas's irreducible plurality of selves, but also that his identity is formed in

\footnotetext{
${ }^{50}$ Christmas's complete genealogy is like the "ghost traveling a half mile ahead of its own shape" (8) Lena ruminates on while awaiting the slow, steady wagon in chapter 1. This image is reminiscent of Zeno's paradox: Joe can only half-approach his always-elusive heritage.

${ }^{51}$ The working title of this novel, Dark House, reveals hints of darker and secretive genealogical patterns which are not easily identifiable ("House"=space of parentage and domestication; "Dark" House= obscured patrimony, heritage, genealogy).
} 
congruence with the identity of others (in other words, he exists "intertextually" with others). The voices whispering to him are the diverse voices which have linguistically molded him into a racially ambiguous, hybrid subject. According to Mikhail Bahktin, the interaction of dialogic voices allows for a freeplay between identity and difference. The dialogic voices perhaps proffer to Joe his identity as "something" not ready-made, as an obscure secret, and as fragmented and multiple in its apparent hybridity. The "dark room" and the "dark house" (indeed, the numerous mention of "dark" and "darkness") symbolize Joe's racial awareness, as if these adjectival phrases were deployed by the narrative voice to remind Joe of his compositeness.

It is this sense of "darkness" clinging onto him at every turn which Christmas tries to repudiate; however, he can only find himself at play with it. Venturing out into the dark night, Christmas frees himself from the confines of his clothing and begins to relish the darkness and coolness of the night: "In the less than halflight he appeared to be watching his body, seeming to watch it turning slow and lascivious in a whispering of gutter filth like a drowned corpse in a thick still pool of more than water" (107). Christmas's eroticized self-assessment of his body juxtaposes his apparently half-white, half-black body with a drowned corpse in a black pool. Even in the texture of the metaphors, Joe cannot dissociate his whiteness from his blackness, and vice versa. He sees his body in the "halflight," which would imply both dimness (a quality of darkness) and lightness - he is nether both and he is both. The heightened sensual imagery and the sophisticated verbal structure of poetic language which follows his excursion to the dark house, wearing nothing but his parchment-colored skin, underscore Joe Christmas's inarticulate negotiation with his otherness, his difference. In other words, Joe attempts to 
reconcile his racial compositeness through the senses: "the dark air breathed upon him, breathed smoothly as the garment slipped down his legs, the cool mouth of darkness, the soft cool tongue" (107; my emphasis). The metaphorical "dark air" breathing upon him symbolizes his black heritage which diffuses throughout his body. Although Christmas cannot fully articulate himself as either a black man or a white one or a hybrid of both (or something else altogether), the self-awareness of his possible biracialism begins to reveal the possibility of effacing the / separating white/black. ${ }^{52}$

As he makes his way from Ms. Burden's house to the road, a car rushes past him, a woman inside the rushing car screaming as she lays eyes on Christmas. The passage is ambiguous and provocative — one is uncertain whether the woman's shriek (which evokes the cry of the Banshee of Gaelic folklore) is an abject expression of terror and recognition of the black body and physicality of the Other. As the headlights dapple him with light, Christmas "watched his body grow white out of the darkness like a Kodak print emerging from the liquid" (108; my emphasis). ${ }^{53}$ The Kodak print functions as a metaphorical snapshot revealing the self and racial identity. His body, steeped in "darkness," now grows "white" by the help of the car's headlights. The interplay between light and darkness (like the interplay between the "Light" in Light in August and the "Dark" of the novel's working title, Dark House) creates a chiaroscuro effect that symbolically suggests his biracialism (even, indeed, the plurality of identity). The text's constant interaction

\footnotetext{
${ }^{52}$ Joe's self-awareness and self-reflexivity may also corroborate Avak Hasratian's description of Christmas as someone who cannot "inhabit the categories of human difference that would allow him to exist within a human community" ("The Death of Difference" 57).

${ }^{53}$ The reference to "liquid" here, as well as the mention of the "thick pool" and the liquid issuing from the "three cracked urns" he envisions during the flashback sequence, all focus on Christmas's preoccupation with the secret of his "true" blood.
} 
between light and darkness will come to define Joe's racial opposition. During this narrative "slippage," however, the text (or Faulkner himself) reveals the fluidities of race and racial boundaries; the Kodak print discloses the conditions of possibility of Christmas's free-flowing racial identities. ${ }^{54}$

Although he can only half-way articulate his difference, Christmas is intuitively aware that his identity is fractured, splintered into diverse contending voices. Once again sitting on his cot in the "Negro cabin," he stares at himself through a shard of mirror: "Nailed to the wall was a shard of mirror. In the fragment he watched his dim face as he knotted the tie" (110; my emphasis). The shard of mirror symbolically exposes the fragmentation of Christmas's identity and his fractured genealogy. In fact, it functions (much like the tin can in "The Bear" or like the Kodak print) as a metonymic/synecdochical entity. The shard of mirror both reflects and forecloses the possibility of a complete and well-defined, articulated subject, one who fully understands his racial history and genealogy. He is always only half-reflected; ${ }^{55}$ he is both light and darkness. As Christmas observes the dawn, he remarks on how it seemed to him that "he could see the yellow day opening peacefully on before him, like a corridor, an arras, into a still chiaroscuro without urgency" (111; my emphasis). During these textual micromoments, Christmas's whiteness and blackness fuse into a fractured chiaroscuro that eschews the strict categorizations and behavioral assumptions of white Southern (patriarchal) society.

\footnotetext{
${ }^{54}$ I wish to contend that the chiaroscuro effect legitimizes the transgression of the white/black boundary.

${ }^{55}$ After Lena moves into Christmas's — and Brown's — cabin and gives birth to her child, she also gazes at herself through the shard of mirror.
} 
Despite the signs and symbols of his compositeness, of his polysemic identities, Christmas, it can be argued, implicitly denies any attempt to live a life like Lucas Beauchamp, a life aware of his hybridity as both a "white man" and a "Negro," and without having to shun either state of being. There are moments, nevertheless, in which Christmas encounters his own radical blackness. Traversing Freedman Town, the black section of Jefferson, Christmas is assailed by "The negro smell, the negro voices" (115). As he hastily rushes through what he considers a "black pit," (115) he feels threatened by the oppressive Negro "voices" and smells and sounds. His desire for the totality of "whiteness" is manifested in the form of a wish—"That's all I wanted" (115)—referring to his desire for peace, and which can be reinterpreted as peace either as a white or a black man. Free from the circumscribing black pit of Freedman Town, he strolls through the white section of town and sights the white gleaming arms of a white woman in a veranda. The sight of the white arms prompts his consummate desire for whiteness; however, this desire is undermined by the reminder of Freedman Town and his brooding attitude stimulated by the introspection of the "negro smells." For Christmas, Freedman Town ironically signifies a lack of light, a black pit of darkness, an abysm. Despite his entrance into the comfort zone of the white section of town, he again hears the voice of his blood: "Nevertheless his blood began again, talking and talking" (116). Joe's unremitting "speaking" blood is a text whose discourse on his otherness and plural, fractured self underscores the freeplay of identity and difference which characterizes him as an elusive and racially ambiguous character.

Curiously, Christmas's desire to consume "whiteness" was made manifest during his early years in a Memphis orphanage. At five years of age, he sneaks into the 
dietician's room and seeks out her pink toothpaste with the intention of consuming it:

"Once in the room, he went directly on his bare and silent feet to the washstand and

found the tube. He was watching the pink worm coil smooth and cool and slow onto his parchmentcolored finger" (120). The "pink worm" of the toothpaste is indicative of the pinkness of the flesh of white persons. In fact, at one point Christmas describes the dietician's face as "pink-and-white" (124), thus corroborating the synonymy between the pinkness of the toothpaste with that of white skin. If, moreover, the pink toothpaste functions both metaphorically and metonymically for white flesh, then the pink worm coiling on his parchment-colored finger indicates a latent, unconscious desire for the metamorphoses of his skin color, as if he could either bleach his skin by consuming the toothpaste, or, like a palimpsest, replace the pinkness of the paste over the (obliterated) parchment-color of his skin. ${ }^{56}$

The consumption of the pink toothpaste validates the fetishization of white flesh. According to Sigmund Freud, the fetishized object stands in for another complex (whether sexual, psychosexual, and so forth); and in this case, the assimilation of the pink toothpaste stands in for a homogenous desire for totalizing whiteness. ${ }^{57}$ Through its oral

\footnotetext{
${ }^{56}$ The pink toothpaste follows the same logic of metonymy/metaphor outlined by David Lodge. Lodge argues that the literary modernist's use of a metonymic style produced "the kind of effect usually associated with metaphorical writing" (491). In this manner, the toothpaste functions as a metonym-for contiguous with the pink toothpaste is the flesh of white persons. On the other hand, this metonym assumes a metaphorical level/significance, since, to use Lodge's terminology, metaphorical meaning emerges from beneath the metonymic surface (492). Therefore, the pink toothpaste is a "substitution" for white flesh, and its consumption forwards Joe's desire to substitute his parchment-colored skin with a "pure" white skin. The significant presence of metonymies/synecdoches in Faulkner's fiction suggests the move toward both the "metonymic as well as metaphoric modes" (Lodge 484) characteristic of Modernist fiction.

${ }^{57}$ Both Marx and Freud presuppose an aura surrounding the fetish (Marx refers to this phenomenon as "the mystical character of commodities" [Capital, Vol. 1 664]); in the context of the novel, this aura is explicitly manifested when Joe spots the white "gleaming" arms of the woman in the veranda, and Joana Burden's "moongleamed" body (260; my emphasis), among other examples. For Marx and Freud, the commodity has an objective value, and in Freud's case "the meaning of the fetish is not known to other people, so the
} 
consumption, the pink paste can metamorphose Joe Christmas into the white-skinned person he perhaps desires to be. Christmas's oral consumption of the pink toothpaste is tantamount to his metaphorical consumption of "whiteness": "By taste and not seeing he contemplated the cool invisible worm as it coiled onto his finger and smeared sharp, automatonlike and sweet, into his mouth" (121). Like a complacent consumer's impulse for mass consumption, Joe is an automaton, esuriently (greedily, gluttonously) stuffing himself without realizing what he is eating.

Christmas's mass consumption of whiteness proliferates when the dietician offers Joe a dollar. Apparently, Joe has been eavesdropping while the dietician had sexual intercourse with an intern. Fearing exposure, she offers the dollar in exchange for his silence; meanwhile Joe, "looking at the dollar, seemed to see ranked tubes of toothpaste like corded wood, endless and terrifying" (125). The (unattainable) vision of the infinite rows of tubes of toothpaste, juxtaposed to the feeling of revulsion and terror which follows, denotes the massive consumption of whiteness as abject/sublime. Because he has consumed a prodigious amount of the pink paste, he experiences a feeling of revulsion; he vomits when he devours more than intended, and the thought of the ranked tubes of toothpaste - the mechanical reproduction of "whiteness" and by extension the decay of its aura—revolt him.

Unfortunately for Joe, the oral intake of the pink paste — the pink flesh—does not remove the hint of "tainted" blood which mystifies his racial status. At first, the dietician remains indifferent to Joe's true racial designation, even while the other children in the orphanage frequently refer to Christmas as "nigger," as if they inherently possessed a through the fetishization of whiteness is contingent upon the "secret" of Joe's "fetish." 
radar whereby to sense racial difference (the "taint") in others (127) ${ }^{58}$ Although the dietician is indifferent to the children's claims, and while the matron of the orphanage remains oblivious to the name-calling, only the janitor (who is later revealed to have been Christmas's white grandfather, Eupheus Hines) knows of his “apparent” black blood. In fact, throughout Light in August, Christmas's genealogy and race is kept a secret. ${ }^{59}$ The ambiguity surrounding his true race is summarized by the people of Mottstown: "He don't look any more like a nigger than I do. But it must have been the nigger blood in him" (349). The source of the "nigger blood in him" remains uncertain and unanswered, leaving gaps or omissions in the text that must be pieced together from the traces of clues left by the fragmentary flashbacks. The truth of Joe's race(s) and genealogy alwaysalready remains a secret, even after, much later in the narrative, his grandparents relate to Hightower the circumstances surrounding the birth of Joe Christmas.

Milly Hines, Christmas's mother, tries to convince Eupheus (Doc) Hines that her paramour - a travelling circus worker - is Mexican; Hines, however, intuits that he "knew somehow that the fellow [Joe's father] had nigger blood. Maybe the circus folks told him. I dont know. He aint never said how he found out, like that never made any difference" (374). The anecdotal reconstruction of Joe's history and genealogy by unreliable, biased narrators obfuscates any “true” account of Joe’s parentage. Encountering Milly and her lover in the dark, Hines kills Milly's lover, without so much

\footnotetext{
${ }^{58}$ However, because Christmas's race and genealogy remain uncertain and ambiguous, the children's designation for Christmas remains under question.

${ }^{59}$ In A Taste for the Secret, Jacques Derrida and Maurizio Ferraris make the claim that "traces" are "at bottom, secrets" (vii). The secret must be revealable in order to be concealed; in fact, the secret, which according to Derrida is never broached, is itself the absolute (A Taste 57). Hence, Joe can never "broach" the absolute, the secret of his true race and parentage. If Joe belongs-i.e., becomes part of a community (whether white or black) - then the secret of his race, paradoxically, is lost; for "belonging...spells the loss of the secret... if a right to the secret is not maintained, we are in a totalitarian space" (59).
} 
as a glance at his face; he therefore fails to corroborate what he earlier intuited. The narrative gaps in the flashback episode disallow a complete picture of Joe's true parentage. The text never provides the reader with a sense of truth or closure. The inconclusive evidence provided by the text disrupts Joe's attempt to fully enunciate his "blackness": "You are worse than that. You dont know what you are. And more than that, you wont never know. You'll live and you'll die and wont never know" (384). This apparent crisis of identity, on the contrary, allows for a space of self-reflexivity whereby Joe's different selves, voices, and fragmented identities can merge and contend, and like the Kodak image/shard of mirror reveal—like a snapshot or like a mirrored reflection— his hybrid sel(f)(ves).

Notwithstanding whether Joe is white/black/Latino, he at first feels a desire to vociferate his alterity to the McEacherns, yet fails to do so: "To say to her [Mrs. McEachern] in secret, in secret payment for the secret dishes which he had not wanted: 'Listen. He [Mr. McEachern] says he has nursed a blasphemer and an ingrate. I dare you to tell him what he has nursed. That he has nursed a nigger beneath his own roof"” (168). Regardless of his initial failure to enunciate his blackness to the McEacherns, Joe manages to half-articulate it during several key narrative moments. These textual "moments," however self-contradicting, showcase Joe "speaking" blackness and "performing" his compositeness. After lovemaking with his girlfriend Bobbie Allen, he decides to tell her his secret. ${ }^{60}$ When he points out his skin and hair, Bobbie joins in by

\footnotetext{
${ }^{60}$ Through the half-articulation of his blackness, Joe tries to conceal the secret of his race. For Derrida, the logic of secrecy presupposes a revealable/concealable paradoxical nature, for it "is never better kept than in being exposed. Dissimulation is never better dissimulated than by means of this particular kind of dissimulation that consists in making a show of exposing it, unveiling it, laying it bare" (Gift of Death 39).
} 
adding that she thought he was a foreigner at one point (196). Yet he is, as Joe specifies,

more than a foreigner:

"It's different from that, even. More than just a foreigner. You cant guess"

"What? How more different?"

Then he told her. "I got some nigger blood in me." (196; my emphasis)

Immediately, however, he corrects himself by adding that he "thinks" he has got "some nigger blood in me.... I don’t know. I believe I have" (196). His apparent comfort with his supposed black blood is indicative, paradoxically, of his unease and discomfort with the secretive knowledge of it; as if by imparting the secret, he both internalizes/externalizes his blackness. ${ }^{61}$ Bobbie at once calls him a liar and refutes the notion until later in the narrative. ${ }^{62}$

After meeting Joana Burden, who prepares his meals every day, they begin a liaison that soon develops into nymphomania. While Burden questions his racial heritage, Joe confesses that he is not sure whether one of his parents was in fact black: "If I'm not [half-black], damned if I haven't wasted a lot of time" (254). This declaration is significant_-Joe's uncertainty gives him the necessary space to embrace potential

The association between dissimulation and secrecy constitutes Joe's paradoxical state of (racial) being, for Joe dissimulates both his whiteness and blackness, never arriving at either state.

${ }^{61}$ Joe speaks (bespeaks) his blackness: "Speaking in order not to say anything is always the best technique for keeping a secret" (Gift of Death 60). Joe speaks or performs "blackness" in order to keep it secret, hidden, indeed occulted. In Of Grammatology, Derrida links the occulted trace with secrecy and dissimulation: "The trace must be thought before the entity [produces rather than is produced by it]. But the movement of the trace is necessarily occulted, it produces itself as self-occultation. When the other announces itself as such, it presents itself in the dissimulation of itself" (47).

${ }^{62}$ Before Bobbie Allen abandons Joe, a stranger (her Memphis employer) beats Joe up, and subsequently wishes to designate Joe's racial identity by examining the color of his blood: "We'll find out. We'll see if his blood is black" (219; Faulkner's emphasis). In this case, the "black blood" that the stranger wishes to see discharged from Joe's body is a socially constructed entity (in other words, the color of blood cannot determine your physiological, psychological, or social being); the "black blood" is thus a cipher revealing Christmas's true racial heritage, his veritable genealogical blueprint. 
difference without adhering to racial norms and the prescriptions of the white community. Moreover, after Joe Brown is relentlessly interrogated by Jefferson's sheriff for the murder of Joana Burden, he casually mentions that he is a white man accused of actions committed by a black person: "Accuse the white and let the nigger run" (97). The sheriff's reaction to the mention of Joe's blackness reveals the quality of abjectness that such knowledge imparts: “"Nigger?' the sheriff said. 'Nigger?”” (98). Brown tells how one day Christmas mistakenly revealed his "nigger blood" to him, possibly while drunk (98). Christmas's "mistake" in articulating his possible "blackness" is a rupture of binary systems - Christmas tries to overthrow the opposition white/black. ${ }^{63}$ The utterance of his racial difference and his immediate retraction of it begins to rupture/reinscribe hierarchical structures of whiteness/blackness. After hearing Brown's anecdote, the marshal recalls: "I always thought there was something funny about that fellow" (99; my emphasis). The phrase "something funny" (which recurs at several points throughout the novel) is revelatory of the implicit understanding of Joe's otherness, an alterity which can only be experienced by his lynching-castration (through the abjection and horror inspired by the blood which explodes from his body). The marshal's declaration not only qualifies the town's reaction and feelings toward Christmas, but displays the town's fear and hatred which they have projected upon the image of the Other. ${ }^{64}$

\footnotetext{
${ }^{63}$ According to Irving Howe, Christmas "tries to reject both roles, the white and the Negro, but is unable to formulate that rejection and must release it through violence ..." (68).

${ }^{64}$ In fact, the first reactions to Joe Christmas in Light in August reveal the town's immediate othering of a potentially "foreign" subject (31-34).
} 
Concomitant with Joe's yearning for whiteness is his desire for blackness. This dual consumption highlights Christmas's ambivalence surrounding his racial affiliations. After the death of his adopted father and the disappearance of his girlfriend Bobbie Allen, Joe wanders through the metaphorical "street" that leads him to different pathways, cities, towns, and jobs. Joe spends 15 years travelling this street; and at this moment another textual rupture posits the fluidity of racial differences. At one point during his "wanderings" he would belligerently fight with whites who would call him "negro" and with blacks who would call him "white" (225). He lives as "husband and wife" in a Negro cabin with a black woman who "resembled an ebony carving" (225). He also lives "with negroes, shunning white people" (225). Consequently, Christmas tries to "breathe into himself the dark odor" as if the airy intake of blackness could consolidate his black identity. In fact, through the intake of the "dark odor" (similar to the eating of the pink worm of toothpaste), Christmas hopes to "expel from himself the white blood and the white thinking and being" (226). The expulsion of whiteness in favor of the intake of blackness — an ontological split rather than an embrace—is Christmas's attempt to dismantle the binary opposition WHITE/black, to negotiate his own fractured identity; in doing so, however, he reverses the binary—now BLACK/white—and inadvertently perpetuates the hierarchical opposition he should otherwise subvert and expunge.

At this point in the narrative, Faulkner's tragic mulatto is evocative of real-life contemporary figures such as, for example, the 1920s Mississippi bluesman Charley Patton, who would play for both a white and a black audience. Patton, himself part-white, part-black, and part-Native American, could easily "perform" one identity or the other, playing country music for his white audiences and hard blues for his black audiences. 
Patton could easily cater to both audiences. Christmas, on the contrary, both refuses/agrees to "cater" to or "perform" for both because of his racial uncertainties, the secret of his race which, like Hightower's sublime visions, continually haunts him. The comparison to Patton - as well as Gavin Steven's discourse on the "middle distance"evokes the conceptualization of "passing" (white as black, and vice versa). "Passing" is precisely what Joe cannot do (or perform) comfortably. Although the sociological aspects of "passing" are pertinent to Light in August, I am dismissing its relevancy in order to focus on the state of in-betweeness or neitherness in terms of the trace. Because textuality issues are foregrounded in my analysis of Light in August, there is not enough space to surmise and discuss Faulkner's politics concerning "passing."

Despite his momentary excursions into the "dark house" of his racial conundrums, his blackness in turn threatens to (playfully) consume him. Before he is captured in Mottstown, Joe at one point swaps shoes with a black woman who has been wearing her husband's coarse brogans. He is forced to wear the black shoes "smelling of negro" (331) as he tries to evade the law; he despises the shoes precisely because they remind him of his blackness. Ironically, the shoe fetish in this case is racialized: “...sitting on the seat, with planted on the dashboard before him the shoes, the black shoes smelling of negro: that mark on his ankles the gauge definite and ineradicable of the black tide creeping up his legs, moving from his feet upward as death moves" (339; my emphasis). The "black tide" is his black heritage that like a palpable entity threatens to overwhelm him. ${ }^{65}$ The brogans "speak" his racial difference. ${ }^{66}$ His introspective mood

\footnotetext{
${ }^{65}$ Or perhaps, to borrow a phrase by James Joyce, the "uncreated conscience of [his] race" (A Portrait of the Artist 244).
} 
prompts the meditation on the "circle" that "the street which ran for thirty years" had made (339). The circle signifies his enclosure within a prescriptive and hierarchical society structured by overbearing strictures that consolidate WHITE/black social and racial relations. The circle acts as a dome shielding a society that ostracizes those who are black (or biracial), and which Joe is unable to escape: "And yet he is still inside the circle" (339).

The circle in which Joe finds himself circumscribed, and which dictates the pattern of circularity his life has assumed, rhymes internally with the elusive and unattainable vision Hightower encounters in the second-to-last chapter in the novel. Staring outside his dark window, awaiting the vision of the Confederate horsemen (his grandfather among them) as they gallop by with brandished sabers and blowing bugles, he suddenly sees the "wheel of thinking" which, according to Hightower, "[engenders] and [surrounds] itself with a faint glow like a halo. The halo is full of faces" (491). Staring profoundly at the interminable succession of faces, faces framed by the ringshaped aureole, he sees among them his own, his late wife's, Byron Bunch's, the townspeople, et al. Finally, he sees the face of Joe Christmas: "This face alone is not clear. It is confused more than any other, as though in the now peaceful throes of a more recent, a more inextricable, compositeness" (491; my emphasis). It is this sense of compositeness which constitutes Joe's fractured identity, and his admixed white and black blood. Looking closer, Hightower notices that it is "two faces which seem to strive

\footnotetext{
${ }^{66}$ Besides the brogans, Christmas's clothing and parchment-colored skin articulate his difference, his chiaroscuro-ness, for him. The continuous mention of his "white shirt and dark creased trousers" underscores - like the emergent Kodak image - the opposition between whiteness and blackness which only an elusive figure like Christmas can efface. Similarly, his parchment-colored skin is the material articulation of his blackness.
} 
in turn to free themselves one from the other, then fade and blend again" (492), noticing the two faces of Christmas and Percy Grimm as they contend and merge, fuse and dissociate. Interestingly, the same language used to describe the bursting of Christmas's pent black blood is deployed again within the context of Hightower's vision: "Then it seems to him that some ultimate dammed flood within him breaks and rushes away" (492). Hightower's wheel of thinking, with its glowing composite of faces, may be reenvisioned and reinterpreted as a (Kodak) photo-album revealing Joe's family tree, and by extension his "secret" race.

Hightower's wheel of thinking in turn rhymes with Joe's vision of the three cracked urns. After Joe's sweetheart Bobbie Allen (who is unbeknownst to him a prostitute) refuses to sleep with him because she is "sick tonight" (188), he runs away hastily and enters the woods at the edge of town: "In the notseeing and the hardknowing as though in a cave he seemed to see a diminishing row of suavely shaped urns in moonlight, blanched. And not one was perfect. Each one was cracked and from each crack there issued something liquid, deathcolored, and foul" (189). These urns, like Uncle Hubert's coffee pot in "The Bear," are not the transcendental urns of truth-essences. ${ }^{67}$ Meanwhile, he leans against a tree, seeing the "ranked and moonlit" urns, and vomits. ${ }^{68}$ The scene is reminiscent of the ranked shelves of toothpaste he envisions while the

\footnotetext{
${ }^{67}$ The row of diminishing urns, suggests André Bleikasten, negatives the Keatsian vase (Ink 287).

${ }^{68}$ The three cracked urns Joe envisions is reminiscent of Sigmund Freud's "The Theme of the Three Caskets." For Freud, throughout diverse literary works (such as Shakespeare's tragedies and the Brothers Grimm fairy-tales), the theme of a subject choosing one casket among three, as in Shakespeare's The Merchant of Venice, is akin to motif of choosing one among three women. In fact, the subject usually ends up with the third woman, who signifies - through her silence-death or the Goddess of Death. Although Freud's specific psychoanalytic lens is not applicable to Joe's vision of the three urns, it is nonetheless necessary to the understanding that Joe does ultimately choose death, a death that can relay his radical (and racial) singularity.
} 
dietician offers him a dollar. These urns, like the shard of mirror, are cracked and fractured, suggesting the indeterminacy of Joe's racial designation. The "deathcolored" liquid which he envisions is arguably his very own dark blood.

The cracked urns and the issuing "deathcolored liquid" Joe imagines, I contend, disrupts pastoral through the intrusion of a "dark" or "racial" sublime. The first chapter in Light in August, in which Lena Grove makes her way into Jefferson, Mississippi, is filled with images and associations attributed to pastoral, of time slowed and stopped. ${ }^{69}$ Joe Christmas intrudes into this pastoral milieu and ultimately displaces it. On the one hand, the first chapter is replete with descriptions of stasis and slowed time, for the pastoral world is Lena's "true milieu, gathering around her as if to shelter her in its seamless and boundless mantle" (Ink 276). Sitting beside the road, Lena contemplates her voyage from Alabama in wagons that were: "like something moving forever and without progress across an urn" (7). The allusion to Keats's Grecian urn solidifies the association with stasis and pastoral simplicity attributed to Lena (she is, in fact, seeking the father of her child in order to marry him and establish a home: the conclusion to her domestication and by extension permanence). Whereas Lena signifies stasis, the "silence and slow time" of Keats's urn, Christmas signifies the disruptive forces of kinesis and mutability. ${ }^{70}$ As Lena awaits the slow-moving wagon, the language of free-indirect discourse deploys images of stasis and slowed time: "Though the mules plod in a steady and unflagging hypnosis, the

\footnotetext{
${ }^{69}$ According to André Bleikasten, the first chapter "celebrates the victory of light and space over the darkness of time and the triumph of the mythic over the actual" (Ink of Melancholy 276-277). And mythology, posits Catherine Clément, "cancels time, and open[s] up space" (qtd. in Bleikasten 277). Bleikasten sees Lena as a synchronic figure (frozen in time) while Joe symbolizes the diachronic - across time - continuity of the "nightmare of history" (Ink 275).

${ }^{70}$ Hence Christmas's vision of the three "cracked urns" and its significance as the "self-destructiveness of modernism" (Howe 205), in contradistinction to Lena Grove who appeals to a more agrarian simplicity.
} 
vehicle does not seem to progress. It seems to hang suspended in the middle distance forever and forever..." (8; my emphasis). The same "middle distance" spatializes the parameters of stasis and containment. The associations between Lena Grove and the imagery of slowed time and the simplicity offered by pastoral underscore her characterization as a representative of pastoral sublimity. ${ }^{71}$ The cracked urns, however, displace pastoral altogether.

The shard of mirror, the multiplicity of voices Joe continuously hears, the Kodak print, the cracked urns, and Hightower's wheel of thinking convey Joe's plurality of selves, his hybridity (either white and/or black and/or Latino). Christmas is not a monolithic, unbroken, homogenous figure; he is polysemic, and the interplay of his two (or three, or four, ad infinitum) identities is negotiated finally at the moment of his death. As I have argued, the completely mapped genealogical picture is the "dark" or "obscured" sublime Joe's racialized blood (the trace) points to and which he can only half-grasp, as any attempts to define, categorize, and decipher that genealogy is ultimately futile and therefore can never be fully realized. While Light in August revolves around Christmas, it never reveals Christmas as such (like Caddy in The Sound and the Fury, Christmas eludes the narrative nets cast by text, Faulkner, reader, World). Faulkner allows us to glimpse elusive shadows, to hear half-whispered rumors of a secret—but Faulkner, partly because of the failure of achieving the sublime, never allows the full presence of Christmas to emerge. Christmas is always-already a racially fluid figure, rendering the boundaries between white and black as nonexistent. Whether Faulkner

\footnotetext{
71 "Grove" is an obvious reference to the wilderness, the woods and nature, while Lena is shorthand for Hellene (or even Helen of Troy); her presence symbolizes the Greek and ideal notion of nature and pastoral.
} 
believed in the plurality of races, in their embracing and intertwining, is irrelevant. What matters is the retention of Christmas's racialized and sensationalized body as he lies castrated and bloodied in Hightower's "refuge". These memories make no difference. Christmas is himself his own refuge. 


\section{CHAPTER THREE}

'The Maelstrom of Unbearable Reality': The Trace as Ghost-Image in Absalom, Absalom!

"To photograph is to appropriate the thing photographed." --Susan Sontag

One way of looking at the trace is as a ghost image, which normally implies grief/loss structures, of residues of the departed. Hitherto the focal point of trace has been Old Ben's spoor and Joe Christmas's dark, racialized blood; the trace can also emerge as a material "thing" humankind holds dear like an heirloom — a photograph. The association between ghosts and photographs prompted Native Americans to believe that a photograph could steal one's soul; in fact, they first avoided being photographed, since the gesture would imply an affront to the spiritual world. The sense of animism was implicitly appropriated by Susan Sontag in her writings on photography. For Sontag, photography miniaturizes a particular moment in time and succeeds in capturing empirical reality. ${ }^{72}$ Sontag, moreover, considers photography within all aspects of social utility. While the camera record incriminates, it also "justifies": "A photograph passes for incontrovertible proof that something happened. The picture may distort; but there is always a presumption that something exists, or did exist, which is like what's in the picture" (175; my emphasis). Sontag stresses the relation between the photograph and the visible, material world, whose relation she considers "more accurate [than] other mimetic objects" (175). Most significantly, a photograph is a trace which bears the absence of

\footnotetext{
72 Sontag considers how photography spatializes/temporalizes certain "real" events and people: "Photographed images do not seem to be statements about the world so much as pieces of it, miniatures of reality that anyone can make or acquire" (“On Photography” 174 ).
} 
presence: "Those ghostly traces, photographs, supply the token presence of the dispersed relatives... photographs give people an imaginary possession of a past that is unreal" (177). A photograph can act as residue of a departed loved one, or could fulfill another social, personal, or historical function.

In Absalom, Absalom! the "trace" is materialized in the form of a photograph, fleetingly beheld by Rosa Coldfield, bearing the image of Charles Bon (Judith Sutpen's suitor and thus an amorous object by proxy for Rosa), a man who has been murdered and whom Rosa has never seen. ${ }^{73}$ The photograph acts as a floating signifier, pointing/not pointing to Charles Bon; indeed the photograph itself has an aura attributed to it by Rosa. ${ }^{74}$ Whereas the focus of the previous chapters has been on the slipperiness of fixed meaning and the imagery/narrative palpability that brings these slippages about, I now wish to emphasize the "dissolution of meaning" which Susan Donaldson locates within the sublime but which I intend to relocate within the metonymic terrain of the trace, and the grief/loss structures embedded therein. My discussion of Absalom, Absalom! consolidates the different interpretive discourses on the trace/sublime found in the two previous chapters; Rosa's encounter with the trace/sublime is pastoral because she wishes for permanence, for the stability of fixed meaning, and "dark" - she indirectly yearns for Charles Bon's black body. In this chapter, however, I will focus on the disruption of Rosa

\footnotetext{
${ }^{73}$ This photo-trace will assume the characteristics of photographs outlined by Susan Sontag.

${ }^{74}$ Walter Benjamin, similar to Freud and Marx, attributes a gleam to certain historical objects, which he terms "aura," a thing's uniqueness and authority. In this fashion, Rosa attributes an aura to the photograph. The aura, which according to Benjamin has no replica, "withers in the age of mechanical reproduction" ("The Work of Art" 221). Namely, the aura of a thing presupposes the "desire...to bring things 'closer' spatially and humanly, which is just as ardent as [the] bent toward overcoming the uniqueness of every reality by accepting its reproduction" (223; my emphasis). The photograph (as a reproduction of reality) destroys the aura (thereby removing the photograph from the fabric of tradition); however, Rosa rejects this overcoming of uniqueness, and "reality" becomes overbearing.
} 
Coldfield's epistemological safeguards - i.e., her sense of security and stability of reliable knowledge and meaning — by the presence of the photograph imprinted with the image of Charles Bon.

Rosa's constant interrogations on the existence of Charles Bon, prompted arguably by her desire to see Bon's murdered body, portend her epistemological breakdown. Her entire narration in chapter five takes on a tone of exasperation as she confronts her own semantic turmoil and empirical limitations; hence her acknowledged preoccupation with "knowing nothing, able to learn nothing" (Absalom, Absalom! 108). For Rosa, Bon is the object of grief, the beloved; on the other hand, she can only experience Bon through the photograph, and this material "historical" object becomes fetishized (much like the pink worm of toothpaste in Light in August). Her grief is therefore spurred by cognitive distantiation and lack of affective proximity to Bon's dead body. Rosa would not value the photograph unless what it points to is not there; the photograph is an aesthetic entity that points to something beyond itself. Her desire to validate—-to "see" and "know" - Charles Bon's physicality is tantamount to her quest for the absolute, to which Rosa aspires but can never attain. ${ }^{75}$ All she will be left with is the memory of the trace, the ghost-image of Bon, and not Bon himself.

In chapter five of Absalom, Absalom! the spinster Rosa Coldfield fervently narrates to a reticent Quentin Compson her flight to Sutpen's Hundred (the plantation

\footnotetext{
${ }^{75}$ For Walter Benjamin, the presence of the original (work) constitutes its authenticity. In fact, authenticity remains irreproducible. Benjamin considers "authenticity" within the purview of historical testimony and the duration of the work: "the authenticity of a thing is the essence of all that is transmissible from its beginning, ranging from its substantive duration to its testimony to the history which it has experienced" ("The Work of Art" 221). The photograph, as a mechanically reproducible thing, jeopardizes both historical testimony and substantive duration. Rosa is unable to authenticate the photograph; she is unable to register it historically.
} 
home forged by Thomas Sutpen) upon learning of her nephew's (Henry Sutpen) murder of his sister Judith's fiancé (Charles Bon, who is Thomas Sutpen's son from his racially mixed first wife). Her lengthy narration relates the burial of Charles Bon in a cedar grove, her time spent at the mansion working with Judith and Clytie (Sutpen's black daughter) relentlessly for their food and clothing, and the arrival of Sutpen himself after the demise of the Civil War, his subsequent plans to restore his plantation, his proposal to Rosa Coldfield—Ellen, her sister and Sutpen's former wife, died two years earlier-, his affront to her, and her removal from Sutpen's Hundred. ${ }^{76}$ The present chapter, therefore, will focus on delineating how Rosa's encounter with the trace/sublime, 1) typifies the postmodernist account of the sublime, in which the imagination runs up against its own limits when it tries to "present" an idea of the absolute $;{ }^{77}$ how 2) Rosa's experience of the trace elicits mourning/melancholia, while the epistemological and semantic crisis—which stems from her failure to "learn nothing"-disrupts boundaries between self/other, knowledge/transcendence, and mind/body, plunging Rosa into a hermeneutical void in which her only recourse is her sensuality (a sensuality which, incidentally, is textual/imaginary), articulated through her use of heightened metaphorical-erotic language; and 3) how this particular chapter-and Rosa's consistent endeavor to connect the signifier to the extra-linguistic signified —is evidently symptomatic of Faulkner's

\footnotetext{
${ }^{76}$ Sutpen's proposition is simple: if Rosa conceives a male child, then they will marry.

${ }^{77}$ According to David B. Johnson, the postmodern sublime relays the "incapacity of the imagination to render a presentation adequate to the unpresentable idea of the absolute" (121). Moreover, Johnson discusses Lyotard's conception of the postmodern sublime; for Lyotard, sublimity entails pain and pleasure (both of which, incidentally, Rosa experiences) that "accompanies the imagination's inevitably failed attempt to present to thought an intuition that would adequately correspond to an idea of the absolute generated by the faculty of reason" (Johnson 120). The irresolvability between presentation and what is unpresentable constitutes Rosa's failed attempt to "present" Charles Bon (for Rosa attempts to cognize the absolute).
} 
larger modernist aesthetic: how history is (re)constructed, the negotiation of past and present, and how a "complete" aesthetic representation of the meaningful part of history is undermined by the descriptive and cognitive "failure" to present the unpresentable.

Sigmund Freud's essay "Mourning and Melancholia" can help facilitate my discussion on Rosa's Coldfield's grief and mourning. Freud makes a comparative study between mourning (the expression of grief) and melancholia. For Freud, mourning entails the normal response to the loss of a loved person or abstraction (164). Mourning, on the one hand, can be surmounted and overcome; melancholia, on the other hand, is characterized by a "morbid pathological disposition" (184). The incapacity to love, painful depression, "inhibition of all activity," loss of interest in the outside world, and expectation of punishment are defining characteristics of melancholy (165). Some of these features apply to grief as well; however, the added components of the fall of selfesteem and harsh self-criticism applies specifically to melancholia. For Freud, mourning is overcome with the severance of the libido from the love-object and its subsequent relocation to another object. In melancholia, the object of loss is uncertain and at times unconscious, while in mourning, there is "nothing unconscious about the loss" of the object of love/desire (166). Yet harsh self-rebuke distinguishes melancholia from normal grief: "The patient represents his ego to us as worthless, incapable of any effort and morally despicable; he reproaches himself...”(167). According to Freud, the loss suffered by the melancholiac may well be that of a tangible object; conversely, the loss may reside within the ego itself. The (pleasurable) self-accusations and self-torments inflicted by the melancholiac onto him/herself are actually reproaches directed towards the object, then redirected towards the ego itself (169). 
Whereas in mourning/grief the libido may sever its attachment to the object of love and reattach itself to another object, in melancholia the libido becomes internalized; in other words, the libido regresses into the ego: "the free libido was withdrawn into the ego and not directed to another object” (170). The proto-melancholiac Freud sketches functions as a blueprint to better understand Rosa's highly constructed and intricate vocabulary of melancholia, eroticism, racial hatred and psychological frustration resulting from the overthrow of her epistemological defenses and her failure to attain the Absolute (in other words, her failure to attain what the photograph points to). Using some of Freud's (and to some extent, Derrida's) ideas on mourning and melancholia liberally, I will demonstrate how the interjection of mourning/melancholia disrupts the pathway or syncope between trace and sublime. ${ }^{78}$ During the melancholia-stage, the melancholiac yearns for the trace of the beloved — what Freud terms the "memory-traces of things" (178). The fact that Rosa has never beheld Charles Bon in his corporeality yet those around her (Judith, Clytie, Ellen Coldfield, Sutpen) have, moreover, plunges her into an abyss where her safe assurance about empirical reality is radically questioned and entirely removed. The only material testimony to Bon's existence is the photo-trace of Bon himself.

\footnotetext{
${ }^{78}$ Derrida undermines the Freudian interpretation of mourning, and this problematic serves to further complicate the structure of mourning/melancholia and its relation to Rosa Coldfield's "loss." For Derrida, there exists an aporia of mourning, the "possibility of the impossible" ("To Reckon" 12); in fact, the formula "success fails" and "failure succeeds" (qtd. in Brault and Naas 12) structures the aporia of mourning. According to Derrida, possible mourning enables one to fully interiorize "within us the image, idol, or ideal of the other who is dead and lives only in us" (qtd. in Brault and Naas 12) while an impossible mourning — which reveals the paradox of fidelity — constitutes a failure to mourn, and therefore "leaving the other his alterity" and "respecting thus his infinite remove, either refuses to take or is incapable of taking the other within oneself" (qtd. in Brault and Naas 12). Rosa's mourning, as I will show, fails precisely because she cannot incorporate the otherness of the other.
} 
In chapter five of Absalom, Absalom!, Rosa Coldfield's frenzied flights of rhapsodic storytelling delineate a certain level of grief and mourning. What exactly does she mourn for? How does mourning disrupt the pathway between trace and sublime? She mourns for-grieves for - the absent "thing" the photograph points to: Charles Bon. Her relentless inquiry into the "actual" existence of Bon begins on her way to Sutpen's Hundred. Wash Jones, who escorts her, cannot seem to articulate what event has transpired, prompting Rosa's anger and frustration at this potential lack of knowledge. This lack intensifies when she is barred by Judith from seeing Bon's corpse. Rosa never sees Bon's corpse; instead she encounters "a picture seen by stealth, by creeping...into the deserted midday room to look at it" (118). The moment in chapter five which demonstrates the encounter with the trace deals with Rosa's repetitive assertion about never having seen Bon, as if through repetition she could negotiate Bon's supposed nonexistence: "I had never seen him...I never saw him. I never even saw him dead. I heard a name, I saw a photograph, I helped to make a grave: and that was all" (117). The signifiers (the sound-name and the photo-image) without a signified prompt Rosa into a crisis of meaning; her crisis is coupled with a warped desire for Bon, a desire she repeatedly disavows: "I did not love him; how could I? I had never even heard his voice, had only Ellen's word for it that there was such a person" (117). The "word" comes not from Bon himself but second-handedly, through Ellen. Moreover, Rosa's incapacity to attain or present what the photograph points to is indicative of her tenuous hold on the reality of events, and in particular her "imaginary possession," to use Sontag's phraseology, of an "unreal" past. 
The fundamental unattainability of Charles Bon, tantamount to the postmodern sublime's foundational concept of the unattainability of the absolute, produces Rosa's mourning/melancholia and by extension her eroticization of Bon. ${ }^{79}$ Rosa loves/grieves over Bon, despite never having laid eyes on him. The lack of "knowing" Bon shatters her perspectival expectations and posits the elimination of her sense of security and stable meaning: "I dont know even now if I was ever aware that I had seen nothing of his face but that photograph, that shadow, that picture in a young girl's bedroom" (118; my emphasis). Her skepticism regarding Bon's actual existence is contingent upon the juxtaposition between the photograph and the shadow, the ghost-image and the physical "face." The perhaps conscious, perhaps unconscious skepticism, moreover, intuits the slipperiness and indeterminacy of fixed meaning. In fact, at one point in the narrative Rosa's skepticism dovetails with her epistemological recoil—she goes so far as to question the validity of her assumptions about Bon's existence: "Why did I not invent, create it?" (118). Charles Bon is Rosa's own mental "shadow" projection.

The epistemological recoil, the sense of displaced security of meaning and stable knowledge signifies for Rosa a "maelstrom of unbearable reality" (120) —an oppressive reality in which certainty about Bon's existence is easily dissolved, nullified, and in which meaning is indeterminate. ${ }^{80}$ To counter the "maelstrom" Rosa deploys language

\footnotetext{
${ }^{79}$ The postmodern sublime stresses the irresolvable conflict between presentation and what cannot be presented. Rosa's self-questioning exemplifies this tendency; according to David Johnson, "the imagination tries to present an intuition of some object that is strictly and intrinsically unpresentable, thereby running up against its own limit" ("Postmodern Sublime" 118). In this case, what is "unpresentable" is Charles Bon's physicality.

${ }^{80}$ Rosa's narrative is symptomatic of the entire novel's (and Faulkner's) concern with "the inextricable confusion of fact and fiction, of observation and interpretation, involved in any account of human experience" (Millgate; qtd. in Fargnoli 1).
} 
suggesting a deeply entrenched desire to return to the womb, where, similar to Ike's woods, she may be safe from "unbearable reality." The continuous deployment of wombimagery crystallizes/consolidates Rosa's desire to return to the origin, the center, the starting point of experience.$^{81}$ The textural language describes the womb-space of her tentative regressiveness: the "projection of the lightless womb" and the "very damp and velvet silence of the womb" (116) become for her a substitutive space in which she could "gestate and complete, not aged, just overdue because of some caesarean lack" (116), but in reality a space in which she no longer submits to the diachronic pressures of reality (whether historical or social), a center in which meaning is fixed, stable and impervious to any outside force (e.g., patriarchal); in essence, a space in which her virginity is consolidated.

The velvety womb-spaces in which Rosa shelters herself are not only a defense and panoply for her own virginity, but also a self-reflexive space whereby she may negotiate the world and the empirical reality she depends on: “...still living in that womblike corridor where the world came not even as living echo but as dead incomprehensible shadow" (131). According to Carolyn Porter, Rosa chooses virginity over marriage to Sutpen as her mode of resistance to dominant patriarchal structures which threaten to consume and constrict her in a society in which the male is the absolute master: "Rosa's exclusion from the role of wife enables her to enunciate the sexual body on behalf of all those denied its pleasures by a patriarchal regime” (“(Un)Making the Father” 193). In

\footnotetext{
${ }^{81}$ In "Structure, Sign, and Play in the Discourse of the Human Sciences" Derrida refutes the notion of center. Meaning cannot be achieved through centeredness, since meaning always defers/differs. For Derrida, the center "closes off the freeplay it opens up and makes possible" (495). Rosa does not embrace the "joyous affirmation of the freeplay of the world," (509) a freeplay which disrupts presence, instead relying on a full presence (Charles Bon) that does not and cannot exist.
} 
Freudian terms, I contend, because Rosa chooses to internalize her libido (relocate the libido within the domain of the ego-a symptom of melancholy) rather than to another object, Rosa develops a "lascivious tribute to the sensual" (Porter 193) through the deployment of highly sexualized imagery and language. While contemplating Sutpen's proposal (and her ironic courtship) she explains to Quentin how a "metabolism of the spirit" exists in which the "stored accumulations of long time burn, generate, create and break some maidenhead of the ravening meat" (132). The use of the vocabulary of libidinal desire underscores Rosa's defense mechanism against the melancholy she suffers at the bereavement of Bon's body.

The trace, the ghost in the photograph, unequivocally haunts Rosa: “...where [Bon] had been but a shape, a shadow: not of a man, a being, but of some esoteric piece of furniture" (120; my emphasis). The absurd relationality between Bon and an esoteric piece of furniture highlights Bon's artificiality and insubstantiality. Bon's shadowy state prompts Rosa's rearticulation and reevaluation of his "supposed" existence. After Rosa enters Sutpen's mansion, she mounts the stairs and comes face-to-face with a placid Judith, barring the door beyond which a murdered Bon lays "crimsoning" the mattress (110). Rosa's bafflement at Judith's calm serenity reassures her crisis of meaning (a crisis that prompts one — even Rosa — to ask "what is going on?" and without a tentative answer). Judith calmly informs Clytie that Rosa will stay for dinner, and that Wash Jones should start preparing the coffin, and "That was all. Or rather, not all, since there is no all, no finish" (121). Rosa intuits the inaccessibility of absolute knowledge, of a final telos in which the sublime/absolute knowledge is at once easily accessible and utterly attainable. Immediately afterward she repeats: "You see, I never saw him. I never even saw him 
dead. I heard an echo, but not the shot; I saw a closed door but did not enter it" (121). Her persistent inquiry and repetitious questioning not only manifests Rosa's crisis - the dissolution of meaning — but also reveals a certain mania apparent in her psychological characteristics.

If Bon's physicality was never indexed by Rosa's empirical registers, could Bon have ever existed at all? "I was one of his pall bearers, yet I could not, would not believe something which I knew could not but be so. Because I never saw him. You see?” (122). The assertive reiteration of "I never saw him" exposes a repetition compulsion to return to the object of desire, but also the need to negotiate Bon's nonexistence. As a matter of fact, as Rosa, Judith, Clytie, and Wash Jones carry the coffin down the flight of stairs, Rosa weighs the coffin and tries to deduce whether a body is actually contained within; she concludes that what they nailed into the coffin was an "abstraction" (123). ${ }^{82}$ Rosa's growing cynicism concerning Bon's existence-which contradicts her love and grief over him — intensifies when she admits that, "For all I was allowed to know, we had no corpse" (123). These paradigms of incompletion or skeptical wanderings, the lack of a corpse, the echo of the shot but not the shot, the unfinished wedding dress with which Judith covers herself as Henry bursts into her room and declares his murderous crime, and others, underscore Rosa's experience of the trace and the association between trace and loss that entails the utter dislocation of meaning.

Rosa visually experiences the photograph of Bon but not Bon himself- the experience results in her valuation of the photograph. Similar to Ike's predetermined

\footnotetext{
${ }^{82}$ Recall that Freud defines mourning/melancholia as the response to the loss of a loved person or "abstraction."
} 
knowledge of Old Ben in "The Bear," Rosa showcases a priori knowledge of Charles Bon: "because even before I saw the photograph I could have recognised, nay, described, the very face. But I never saw it. I do not even know of my own knowledge that Ellen ever saw it, that Judith ever loved it, that Henry slew it" (118). Her inability to negotiate the existence of Charles Bon — to match signifier with signified—leads to the melancholization of her mental features and linguistic patterns. To return to Susan Sontag's theorization on photography, Rosa cannot presume that "something existed..."- that what is in the photograph ever was. ${ }^{83}$ Rosa lacks incontrovertible proof that Bon existed; Rosa cannot appropriate the thing photographed. ${ }^{84}$

Her constant repetition of "I never saw him" as well as several other key phrases typifies the repetition compulsion inherent in most cases of neurosis. ${ }^{85}$ As a result of this repetition compulsion, epistemological recoil, and mourning/melancholia, Rosa's narration contains images which characterize her disruptive—and disrupted—psyche. In fact, as her account gains forte, sounding like an exulted diatribe, the narrative's verbal dexterity begins to showcase the collapse of her emotional, epistemological, and psychological structures of meaning. As she makes her way sluggishly to Sutpen's Hundred with Wash Jones, she refers to the mule tugging them as a "chimaera-foal of

\footnotetext{
${ }^{83}$ The sense of matching signifier with signified, of the tenuous, ambiguous relationship between photography and the world, and the logic of "seeing" and "knowing" what the photograph points to also constituted the thematic of Michelangelo Antonioni's 1966 film, Blow- $U p$, in which a young professional photographer inadvertently takes pictures of a murder; the film's conclusion finds the photographer at the 'scene of the crime' but without the body present, its absence heightened by its former imprint on the ground.

${ }^{84}$ Or, as Freud puts it, the ego "wishes to incorporate this object into itself" (171).

${ }^{85}$ For example, Rosa begins her narration with a phrase which will be repeated throughout: "So they will have told you doubtless already" (107); as if she herself possessed an intuitive awareness of how knowledge ("history") is disseminated through word-of-mouth. Perhaps the constant repetition of key phrases signifies a transition from melancholia to mania.
} 
nightmare's very self' (113). This sublime nightmare constitutes her current state of being: "I found only that dream-state in which you run without moving from a terror in which you can not believe, toward a safety in which you have no faith" (113; my emphasis). The juxtaposition between terror and displaced safety/groundedness not only characterizes the sublime, but also bespeaks Rosa's hermeneutical crisis, a crisis which disrupts all signification. Dreams, chimaeras, the displacement of safety, the nightmarish landscape which Rosa inhabits undermine her familiar patterns of knowing and understanding.

Rosa's acknowledgement and acceptance that "Ay, grief goes, fades" (115) reveals her comprehension of the structures of grief involved in her tenable loss. Rosa desires the prolongation of her mourning/melancholia, and the textual repetitions of the "eternal black which she had worn for forty-three years now" and the "air of impotent and static rage" (3) directed toward Sutpen justifies Rosa's preoccupation with the abatement of her satisfaction-generating neurosis. This point is analogous to Quentin Compson in The Sound and the Fury being not so worried about Caddy's loss of virginity, but that he may end up no longer concerned about said loss. In other words, he - as well as Rosa — fears that time will rob him of the intensity of his mourning/melancholy.

Since Rosa's familiar patterns of understanding and structures of meaning have collapsed due to the presence of the photograph that points to something she cannot access and define, reality for her becomes not only "unbearable" but ineluctable: "See how the sleeping outflung hand, touching the bedside candle, remembers pain, springs back and free while mind and brain sleep on and only make of this adjacent heat some 
trashy myth of reality's escape" (115; my emphasis). The evaluative "trashy myth of reality's escape" summarizes or negotiates the way she perceives empirical reality. For Rosa, reality is warped, "trashy," and as a result prompts the removal of safety and groundedness which epistemological and semantic security afforded her ${ }^{86}$ These signs of elaborate verbal discharges perhaps suggest that Rosa's melancholia has developed into mania; ${ }^{87}$ the narrative account of her experience with the trace reveals symptoms of melancholia: pain, dejection, and self-criticism. Her melancholy, therefore, indicates that Rosa has failed to reattach libidinal desire to another object.

Rosa's failure to relocate libidinal energy elsewhere (transference to another object) results in the internalization of the libido (libido withdraws into the ego) and is subsequently manifested in her use of the vocabulary of sexual and erotic desire. As she recounts the summer when she was fourteen years old, Rosa's language become highly eroticized: “But it was no summer of a virgin's itching discontent; no summer's caesarean lack which should have torn me, dead flesh or even embryo, from the living: or else, by friction's ravishing of the male-furrowed meat, also weaponed and panoplied as a man" (117). Rosa's internalization of libidinal energy prepares her-“weaponed" and “panoplied"- for her resistance against Sutpen's affront; her textual language bespeaks

\footnotetext{
${ }^{86}$ Rosa's turning away from reality (her retrieval into the womb-space) effects what Freud calls a "hallucinatory wish-psychosis" ("Mourning" 166). Hence the "eternal black which she had worn for fortythree years now" ( $A A 3$ ), the prolongation of her virginity, and her perpetual state of bafflement by the death of Sutpen and her inability to enact a vendetta against him. However, as I contend, her "retrieval" is the effect not of her association with Sutpen but because of her grief over Bon.

${ }^{87}$ According to Freud, there is a slipperiness between the states of melancholy and mania: "the content of mania is no different from that of melancholia" ("Mourning" 175). In contrast to Rosa's inhibition of activity are her mania-inspired discharges: "all such situations are characterized by high spirits, by the signs of discharge of joyful emotion, and by increased readiness to all kinds of action, just like mania, and in complete contrast to the dejection and inhibition of melancholia" ("Mourning" 175).
} 
jouissance, a jouissance that disallows its subsumption into strict patriarchal "standard" regimes. Because Rosa fails to reconcile signifier with signified, to "present an intuition corresponding to an idea of the absolute," her recourse lies in the deployment of the playful vocabulary of sexual desire and sensual imagery.

In fact, the palpable erotic structure of her use of sexualized language/imagery begins at the very beginning of chapter five, when she informs Quentin that Wash Jones's (who eventually kills Sutpen) “granddaughter was to supplant me, if not in my sister's house at least in my sister's bed to which (so they will tell you) I aspired" (107). The juxtaposition of the compulsively repeated phrase- "So they will tell you"-with the connubial bed underscores Rosa's hyper-frenzied melancholia, a "morbidly pathological disposition" expressed in erotic terms. The connubial bed becomes the "cocoon-casket marriage bed" (108); the cocoon-casket rhymes internally with the womb—Rosa continuously seeks shelter, the "reality's escape." Her oversexualized narrative is the effect of the internalization of libidinal energy, and in a way these discharges work as a counterforce to Sutpen's affront.

Rosa's excessive verbiage also subsumes within its all-encompassing framework the language of race and racial hatred. As Rosa arrives and rushes into Sutpen's mansion, she comes face-to-face with Clytie, who "bars" the stairwell. She instantly emphasizes Clytie's "blackness" as she gradually reveals symptoms of racial hatred: "It was not Henry's face. It was Sutpen face enough, but not his; Sutpen coffee-colored face enough there in the dim light, barring the stairs" (109). Rosa sees Clytie as a "rocklike and immobile antagonism" (110) impeding her entrance into the stairwell and thence into a physical space in which knowledge of occurrences (the "something happened" Sontag 
speaks about) will be divulged to her. In other words, Clytie symbolically bars Rosa from surmounting her own empirical limitations; more importantly, she impedes her from glimpsing Bon's dead body. Rosa can anticipate the moment in which she will attain that knowledge, and this "yearning" becomes symptomatic of her need for closure and fixity: “...which created postulated and shaped in the empty air between us [Clytie and Rosa] that which I believed I had come to find (nay, which I must find, else breathing and standing there, I would have denied that I was ever born)" (110). Rosa must know; she must have closure.

Rosa, like the Freudian melancholiac, engages in self-criticism and self-torment, suggesting that these reproaches are actually directed to another object, presumably Bon. Rosa refers to herself as a "self-mesmered fool" who "still believed that what must be would be, could not but be" (110). Although they are "sworn enemies" Clytie nevertheless provokes a certain horror in Rosa. Clytie's utterance of the name "Rosa" and her touch — "Then she touched me, and then I did stop dead" (111)—reveals the sense of horror and abjection projected upon the image of the Other. The moment Clytie touches Rosa is a textual moment illustrating the dissolution of meaning, and, arguably, the moment in which racial boundaries are dissolved: "Because there is something in the touch of flesh with flesh which abrogates, cuts sharp and straight" (111). The "touch" is tantamount to a transgression of the boundaries normally defining whiteness/blacknessthe touch, in other words, is an eruption of unsustainable binary systems.

Rosa confesses to Quentin her refusal to lay hands on any object previously touched by Clytie; she detains from any physical association with her. As a matter of fact, she learns to completely shun Clytie as a child, fearing her and directing deep feelings of 
hostility toward her. Her fear of the Other relays a mania for racial hatred; her fear rests on the terror of a potential unison of whiteness and blackness, a subsuming of blackness into the realm of whiteness: "But let flesh touch with flesh, and watch the fall of all the eggshell shibboleth of caste and color too" (112). The eradication of boundaries defining race, class, and gender stems from this initial physical contact. Subsequently, Rosa gains the stairwell and makes her way to the upper hallway; she finds Judith calmly barring the door beyond which Charles Bon's supposed "pale and bloody corpse" lays (110). The deployment of the language of racial hatred, of womb-imagery, and of mourning and melancholia all relay the degree of uncertainty and skepticism concerning the phenomenality of events. Perhaps, Rosa believes, there never was a Charles Bon.

The skepticism and uncertainty surrounding the phenomenality of events, the "reality" behind the reality of real-life occurrences, is also found to be the case with Quentin Compson. In the second-half of the novel, Quentin converses with his Canadian friend and Harvard roommate, Shreve MacCannon, as they try to reconstruct the missing gaps from Sutpen's history, his relation to Charles Bon, as well as the incestuous triangle Bon-Judith-Henry, which inevitably reminds him of his own obsession with the everabsent Caddy. The structure of mourning/melancholy Rosa suffers from, arising out of the epistemological crisis — that of "knowing nothing" and unable to learn anything —is replicated with Quentin. Quentin also knows nothing, can learn nothing, and consequently suffers the same mourning/melancholia as Rosa. After Quentin and Rosa venture to Sutpen's mansion, they find hidden there an aged Henry Sutpen. Having encountered the moribund Henry Sutpen, Quentin skeptically questions him: 
And you are-?

Henry Sutpen.

And you have been here-?

Four years.

And you came home-?

To die. Yes.

To die?

Yes. To die.

And you have been here-?

Four years.

And you are-?

Henry Sutpen. (298)

The sense of circularity - the repetition of the same sequence of questions - reveals Quentin's own dislocation of meaning, the going-back-and-forthness in a semantic labyrinth. The recurring "And you are-??" and "And you have been here-?" as well as "To die?" suggests that Quentin himself suffers from the same epistemological recoil; he too has been plunged into the hermeneutical void. While Henry responds in staccato, assertive sentences, Quentin's interrogation-like questioning reveals a sense of urgency, of skepticism, and invariably of self-doubt. It seems as if Quentin cannot recognize (or surmise) Henry's existence, just as Rosa could not accept Bon's being. This sense of notknowing and not-believing is also articulated when Quentin is aligned with Henry Sutpen:

So that now it was not two but four of them riding the two horses through the dark over the frozen December ruts of that Christmas eve; four of them and then just two-Charles-Shreve and Quentin-Henry...Henry who knew but still did not believe...(267); since now both of them were Henry Sutpen and both of them were Bon, compounded each of both yet either neither... (280)

The alignment with Henry suggests that Quentin too knows but still does not believe. Moreover, Quentin becomes Henry; he internalizes Henry's own endeavor, that of disallowing the abatement of the intensity of his mourning/melancholia. In short, Henry's 
(like Quentin's) dilemma is not so much the incest or the miscegenation (Bon, Judith's suitor, has "black blood" in him) but rather the dwindling of the force of his interest in said dilemma. Henry, like Quentin and like Rosa, also partakes of a certain delight and satisfaction from his neurosis. If, however, Quentin suffers the same mourning/melancholia as Rosa, then perhaps his own libido has recathected to another object(s), in this case the triadic Henry-Bon-Judith.

Rosa's experience of the trace/sublime (which exposes the failure to attain the absolute) prompts a critical reflection on her own limits and conditions of experience-in other words, the conditions of possibility to (re)present history and the materiality of history. The irresolvable conflict between presentation and the unpresentable should make no difference to Rosa. Rosa's last resort, therefore, is the memorialization of the metonymic/synecdochical photograph. As an alternative to the unbearable reality she is thrust upon, Rosa cocoons herself in the velvety silences of the womb, and internalizes her libidinal energy, thus deploying mania-inspired discharges of joyful energy in the form of sexualized erotic language and imagery. ${ }^{88}$ As a result of this eroticization, Rosa becomes "all polymath love's androgynous advocate" (117). Whereas presumably Rosa's frenzy, melancholia, or anger stems from her inability to enact vendetta against Sutpen (she is angry at Sutpen for having died), it is, as I contend, Charles Bon himself she grieves over and to whom she directs her reproaches. Bon is the sublime object of desire;

\footnotetext{
${ }^{88}$ This excessive verbiage may also be a symptom of "thinking's getting carried away... as if fascinated by its own excessiveness" (Lyotard; qtd. in Johnson 120). Rosa's tantalizing language reveals her attempt to discover the absolute, since, according to David Johnson, thought is attracted to "transcendental illusions... in sublime experience, thought tantalizes itself, as it were, with the possibility of discovering the absolute in phenomenal intuition by transgressing its own boundaries" (Johnson 120). In a way, Rosa gives "voice" to these thoughts.
} 
the photograph (like the spoor or the dark blood) mediates but does not lead to the transcendental, absolute sublime. ${ }^{89}$ Rosa is the quintessential melancholiac, although she progresses into mania gradually. Whereas Rosa tries to appropriate/incorporate Bon, Bon resists the introjection of his body, his otherness. ${ }^{90}$ As a matter of fact, Rosa is the other; the other is in her.

\footnotetext{
${ }^{89}$ Jean-Francois Lyotard argues that the sublime thing "is presence as unpresentable to the mind, always withdrawn from its grasp. It does not offer itself to dialogue and dialectic" (qtd. in Shaw 130). In a similar fashion, Bon does not offer himself to dialogue and dialectic.

${ }^{90}$ According to Derrida, "memory and interiorization" normally constitutes the work of mourning; in fact, it "entails a movement in which an interiorizing idealization takes in itself or upon itself the body and voice of the other, the other's visage and person, ideally and quasi-literally devouring them" (qtd. in Brault and Naas 9). Rosa has interiorized (i.e. metaphorically consumed) Charles Bon; he speaks in Rosa, through Rosa. Rosa, however, cannot approach him or broach him in his "infinite alterity" ("To Reckon" 11). In other words, Charles Bon "resists the closure" of Rosa's "interiorizing memory" (qtd. in Brault and Naas 11). By resisting this closure, Charles Bon's infinite alterity and singularity is preserved.
} 


\section{CONCLUSION}

In Marcel Proust's Remembrance of Things Past, as in William Faulkner's work, the same logic of the absent-present trace is questioned and put into perspective. The "episode of the madeleine" sheds light on how material markers point to something beyond the reach of the intellect or cognition. For Proust the past is secretly hidden (or occulted) in some material object; this object functions as a cue that triggers in the spectator an overwhelming sensation not unlike the sublime. Proust himself is aware of the limitations marking the presentation of the sublime, and furthermore how the trace mediates the sublime experience while never fully leading to it. There is an inevitable parallelism between Proust's and Faulkner's conception of the vulnerability of the imagination in the face of the absolute. For both writers, the quest for the absolute sublime is a highly subjective experience.

What I have tried to illuminate through this project is the two-fold thematic which characterizes Faulkner's modernist fiction: underlying Faulkner's oeuvre is a sense of traditionalism, of a primal, earthy quality, and post-Civil War angst; on the other hand, Faulkner's works (and in particular the three selected texts) bring Derridean theory to earth. Hence, Faulkner is at the same time postmodern (or hyper-postmodern) in this regard. In other words, Faulkner gives us a sophisticated deconstructive understanding of the trace/sublime. Yet the palpability of Faulkner's narrative/imagery suggests a movement beyond theory, beyond the grasp of any conceptual or theoretical framework. In Faulkner's textual universe, anything as apparently simple as a tin can, a tube of pink toothpaste, a photograph, a shard of mirror, is full of contradictory meanings. I have used "trace" and "sublime" as philosophical and methodological tools to trace the basic truth- 
claims of these texts to fundamental points of paradox or contradiction. By pointing out moments of rupture or aporia, the irreconcilable meanings that exist at the margins of the text, and by articulating them, the beauty of Faulkner's paradoxes come to light. Yet this "light" is always hidden behind a darker shade of the sublime.

The aforementioned narrative/imagery palpability that characterizes Faulkner's writing style is also indicative of his primarily pictorial imagination. The trace, for Faulkner at least, always materializes as a tangible "thing" fundamentally connected to the material world (the sociological), while the sublime remains intangible and inaccessible (the metaphysical). The duality between the cultural/sociological and the metaphysical—often thought of as antithetical—complement each other profoundly in Faulkner's oeuvre. Arguably, these sociological issues (land possession, the destruction of pastoral by industrial capitalism, race angsting) lead to fundamental identity issues that then translate into the failed quest for the sublime via the trace. We see this tension at work in the texts themselves, through the character of Joe Christmas, for example, whose failed quest to attain the sublime (his true parentage/genealogy) sheds light on the identity issues which permeate his social and racial being. Therefore, the trace and the sublime relay the sociological vs. metaphysical pressures at work in Faulkner's texts.

Faulkner's pictorial imagination, on the one hand, interests me in the sense of a primal dream image — for arguably Faulkner sees these traces as leading to an originary presence, an "absolute" past. Faulkner falls into textuality to explicate and narratively trace the impossible and indecipherable trace. Old Ben's spoor, Joe Christmas's black blood, and the photograph are the three traces upon which nearly the entire narrative in each case necessarily revolves. These traces are effects of Faulkner's pictorial 
imagination, and in each case Faulkner makes sure to underscore their primal, earthy qualities. Although his texts, according to him, will remain "failures," one should not dismiss how his pictorial imagination translates into textual sublimity. 


\section{BIBLIOGRAPHY}

Arensberg, Mary and Sara E. Schyfter. "Hairoglyphics in Faulkner's 'A Rose for Emily'/Reading the Primal Trace”. Boundary 2, Vol. 15, No. 1/2 (Autumn, 1986 Winter, 1987), pp. 123-134 Duke University Press. Jstor. 02/01/2013.

Benjamin, Walter. "The Work of Art in the Age of Mechanical Reproduction." Illuminations. New York: Schocken Books, 1978. Print.

Bleikasten, André. The Ink of Melancholy. Indianapolis: Indiana University Press, 1990. Print.

Borges, Jorge Luis. "William Faulkner: The Unvanquished." Selected Non-Fictions. New York: Penguin Books, 1999. Print.

Brault, Pascale-Anne and Michael Naas. "To Reckon with the Dead: Jacques Derrida's Politics of Mourning." The Work of Mourning. Chicago: The University of Chicago Press, 2001. Print.

Burke, Edmund. Philosophical Enquiry into the Origin of Our Ideas of the Sublime and Beautiful. The Norton Anthology of Literary Criticism. Ed. by Vincent B. Leitch et al. W. W. Norton \& Company, Inc. New York, New York. 2010. Print.

Clarke, Deborah. "Gender, Race, and Language in Light in August." American Literature, 61.3 (1989): 398-413.

Costelloe, Timothy. "Imagination and Internal Sense: The Sublime in Shaftsbury, Reid, Addison, and Reynolds." The Sublime: From Antiquity to the Present. Ed. Timothy Costelloe. New York: Cambridge University Press, 2012. Print.

Danner, Bruce. "Epic Tears: The Dislocation of Meaning in Faulkner's 'The Bear.'” Mississippi Quarterly. 271-294. Web.

Derrida, Jacques and Maurizio Ferraris. A Taste for the Secret. Malden, MA: Blackwell Publishers Inc, 2001. Print.

Derrida, Jacques. "Structure, Sign, and Play in the Discourse of the Human Sciences". Criticism: Major Statements. Ed. Kaplan, Charles. Boston: Bedford/St. Martin's, 2000. Print.

---. "Différance." trans Alan Bass, Margins of Philosophy, Chicago: University of Chicago Press, 1982: 3-27. Web.

---. Of Grammatology. Baltimore: John Hopkins University Press, 1997. Print. 
---. The Gift of Death. Chicago: The University of Chicago Press. 2008. Print.

Donaldson, Susan V 2007. "Faulkner's Versions of Pastoral, Gothic, and the Sublime." The Companion to William Faulkner. Ed. Richard C. Moreland. Oxford: Blackwell, pp.359-372.

Fargnoli, Nicholas and Michael Golay. William Faulkner: A to Z. New York: Facts On File, Inc., 2002. Print.

Faulkner, William. Absalom, Absalom! New York: Vintage International, 1990. Print.

---. Go Down, Moses. New York: Vintage International, 2011. Print.

---.. Light in August. New York: Vintage International, 1990. Print.

---. "A Rose for Emily." Selected Short Stories of William Faulkner. New York: Modern Library, 1993. Print.

Finkelstein, Sidney. "Conflict Between Humanization and Alienation: William Faulkner." Existentialism and Alienation in American Literature. New York:

International Publishers Inc., 1965. Print.

Freud, Sigmund. "Mourning and Melancholia." General Psychological Theory. New York: Collier Books. 1974. Print.

---. "Fetishism." The Norton Anthology of Literary Criticism. Ed. by Vincent B. Leitch et al. W. W. Norton \& Company, Inc. New York, New York. 2010. Print.

Gasché, Rodolphe. "And the Beautiful? Revisiting Edmund Burke's 'Double Aesthetics.' The Sublime: From Antiquity to the Present. Ed. Timothy Costelloe. New York:

Cambridge University Press, 2012. Print.

Godden, Richard. "Bear, Man, and Black: Hunting the Hidden in Faulkner's Big Woods." The Faulkner Journal. 2007.

Hasratian, Avak. "The Death of Difference in Light in August." Criticism, 49.1 (2007): $55-84$.

Howe, Irving. William Faulkner: A Critical Study. Chicago: Elephant Paperback, 1991. Print.

Johnson, David B. "The Postmodern Sublime: Presentation and Its Limits." The Sublime: From Antiquity to the Present. Ed. Timothy Costelloe. New York: Cambridge University Press, 2012. Print. 
Joyce, James. A Portrait of the Artist as a Young Man. New York: Vintage International, 1993. Print.

Kodat, Catherine Gunther. "Making Camp: Go Down, Moses. American Literary History. 19.4 (2007): 997-1029.

Lodge, David. "The Language of Modernist Fiction: Metaphor and Metonymy." Modernism: A Guide to European Literature. Ed. by Malcolm Bradbury and James McFarlane. New York: Penguin Books, 1991. Print.

Longinus. On Sublimity. The Norton Anthology of Literary Criticism. Ed. by Vincent B. Leitch et al. W. W. Norton \& Company, Inc. New York, New York. 2010. Print.

Luciano, Dana. "Melville's Untimely History: 'Benito Cereno' as Counter-Monumental Narrative." Arizona Quarterly. 60.3 (2004): 33-60.

Marx, Karl. Capital, Volume 1. The Norton Anthology of Literary Criticism. Ed. by Vincent B. Leitch et al. W. W. Norton \& Company, Inc. New York, New York. 2010. Print.

Miller, J. Hillis. "Trace." Reading Derrida's Of Grammatology. Ed. Sean Gaston and Ian Maclachlan. New York: Continuum International, 2011. Print.

Murfin, Ross C. "What is Deconstruction?" Hamlet. Ed. Susanne L. Wofford. New York: Bedford/St. Martin's, 1994. Print.

O’Donnell, Patrick. "Faulkner and Postmodernism." The Cambridge Companion to William Faulkner. New York: Cambridge University Press, 1995. Print.

Porter, Carolyn. "Absalom, Absalom!: (Un)Making the Father.” The Cambridge Companion to William Faulkner. New York: Cambridge University Press, 1995. Print.

Shaw, Philip. The Sublime. New York, New York: Routledge, 2006. Print.

Sontag, Susan. "On Photography.” Web. 09/10/2013.

http://www.rcbsam.com/uploads/4/1/9/6/41960/sontag_on_photography.pdf

Weinstein, Philip M. The Cambridge Companion to William Faulkner. New York: Cambridge Unitersity Press, 1995. Print.

Wittenberg, Judith Bryant. "Race in Light in August: Wordsymbols and Obverse Reflections." The Cambridge Companion to William Faulkner. New York: Cambridge University Press, 1995. Print. 